\title{
Metabolic comorbidities in Cushing's syndrome
}

\section{Francesco Ferraù and Márta Korbonits}

Centre for Endocrinology, William Harvey Research Institute, Barts and the London School of Medicine, Queen Mary University of London, Charterhouse Square, London EC1M 6BQ, UK

Correspondence should be addressed to M Korbonits Email m.korbonits@qmul.ac.uk

\begin{abstract}
Cushing's syndrome (CS) patients have increased mortality primarily due to cardiovascular events induced by glucocorticoid (GC) excess-related severe metabolic changes. Glucose metabolism abnormalities are common in CS due to increased gluconeogenesis, disruption of insulin signalling with reduced glucose uptake and disposal of glucose and altered insulin secretion, consequent to the combination of GCs effects on liver, muscle, adipose tissue and pancreas. Dyslipidaemia is a frequent feature in CS as a result of GC-induced increased lipolysis, lipid mobilisation, liponeogenesis and adipogenesis. Protein metabolism is severely affected by GC excess via complex direct and indirect stimulation of protein breakdown and inhibition of protein synthesis, which can lead to muscle loss. CS patients show changes in body composition, with fat redistribution resulting in accumulation of central adipose tissue. Metabolic changes, altered adipokine release, GC-induced heart and vasculature abnormalities, hypertension and atherosclerosis contribute to the increased cardiovascular morbidity and mortality. In paediatric CS patients, the interplay between GC and the GH/IGF1 axis affects growth and body composition, while in adults it further contributes to the metabolic derangement. GC excess has a myriad of deleterious effects and here we attempt to summarise the metabolic comorbidities related to CS and their management in the perspective of reducing the cardiovascular risk and mortality overall.
\end{abstract}

\section{Introduction}

Cushing's syndrome (CS) is a severe disease due to the complications of glucocorticoid (GC) excess (Fig. 1). The increased morbidity and mortality in these patients is due to the cardiovascular, thrombotic, metabolic, infectious and musculoskeletal complications $(1,2,3)$. To understand, treat and ideally prevent these complications is a major challenge to the treating physician and the multidisciplinary team looking after the patient. These issues

\section{Invited Authors' profiles}

Prof. Márta Korbonits, MD, PhD, DSc, FRCP is a clinical academic endocrinologist. Her current interests include endocrine tumorigenesis and the metabolic regulation of AMP-activated protein kinase.

Dr Francesco Ferrau originally from Messina, Sicily, Italy, was a recent visiting PhD student at Barts and the London School of Medicine, where he studied the aetiology and pathogenesis of pituitary adenomas for his PhD.

(C) 2015 European Society of Endocrinology Printed in Great Britain Published by Bioscientifica Ltd.
This article is adapted from work presented at IMPROCUSH-1, 12-14 October 2014. The meeting was supported by the European Science Foundation, Deutsche Forschungsgemeinschaft, Carl Friedrich von Siemens Stiftung, European Neuroendo-

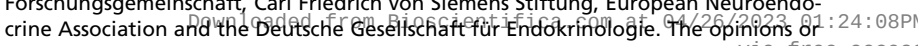
views expressed in this article are those of the authors, and do not necessarily reflecte access the opinions or recommendations of the supporters of the symposium. 


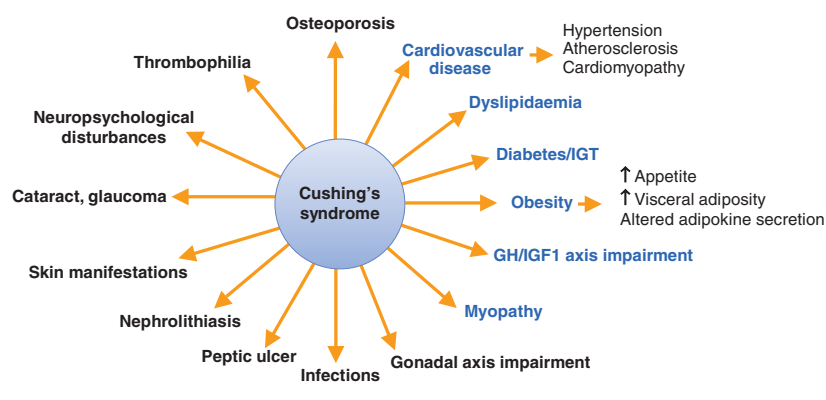

\section{Figure 1}

Cushing's syndrome comorbidities. CS is associated with numerous deleterious changes in various organ systems. The ones discussed in this review are marked with blue. IGT, impaired glucose tolerance.

are further complicated in patients with iatrogenic CS, where the underlying disorder often contributes to increased cardiovascular and musculoskeletal complications. This review focuses on the pathomechanisms and clinical consequences of the interrelated deleterious effects of GC excess on glucose, lipid and protein metabolism and on the changes observed in adipose tissue, muscle and cardiovascular system as well as on the growth hormone $(\mathrm{GH}) /$ insulin-like growth factor 1 (IGF1) axis. GC-excess related thrombotic complications, which further contribute to the CS-associated high mortality rate due to cardiovascular disease, will be specifically addressed in another review of this issue of the European Journal of Endocrinology.

\section{GCs and glucose metabolism}

Glucose metabolism alterations are common in CS: overt diabetes mellitus (DM) is diagnosed in $20-47 \%$ of the patients (4), while impaired glucose tolerance (IGT) is present in $21-64 \%$ of cases $(4,5)$. No significant gender differences have been reported (6). Diabetic CS patients have been found to be older than normoglycaemic or prediabetic CS patients (7). Nevertheless, reported prevalence could be underestimated because available data were largely based on the measurement of fasting blood glucose. Indeed, in a study of 48 patients with active Cushing's disease (CD), over two-thirds of those with diabetes had been diagnosed by an oral glucose tolerance test (OGTT), thus confirming the inaccuracy of the fasting blood glucose for assessing the prevalence of diabetes in CS (8). Therefore, an OGTT has been suggested in all patients with endogenous CS (9).
Increased DM prevalence has been reported in ectopic (74\%) compared to pituitary (33\%) and adrenal (34\%) CS (10). This indirectly suggests that the degree of cortisol excess can be relevant for the development of altered glucose metabolism. No definitive data are available to link the duration of CS with glucose tolerance abnormalities. Alterations of glucose metabolism can persist after the remission and cure of CS (4). The prevalence of CS in diabetic populations has been studied and data suggest that routine screening of patients with DM for CS is not recommended (11). Several prospective screening studies of diabetic patients who lack specific clinical symptoms of hypercortisolism revealed a prevalence of CS that reaches $3.3 \%$ (12). More recently, only $0.6 \%$ of a large cohort of diabetic patients unselected for signs or symptoms suggestive of hypercortisolism have been found to be affected with CS. A case finding approach to identify CS is recommended in patients with diabetes and hypertension who are difficult to control despite complex treatment (13). The prevalence of abnormal glucose tolerance is controversial in patients with subclinical CS (sCS), depending on the criteria adopted to diagnose sCS and DM $(14,15)$. Data from some studies in which OGTT results are available suggest that there is no significant difference in the prevalence of IGT or DM in patients with sCS due to an adrenal adenoma compared to nonfunctioning adrenal lesions (14). On the other hand, a large study found an increased prevalence of DM, diagnosed according to the American Diabetes Association guidelines, in adrenal adenoma patients with sCS compared to those with non-functioning adrenal lesions (16). Similarly, a recent investigation carried out on 268 patients with adrenal incidentaloma demonstrated that HbA1c was significantly increased in sCS compared to subjects harbouring non-secreting lesions, suggesting an adverse metabolic profile in sCS patients, in line with other previous reports based on fasting glycaemia and insulin levels (17). Accordingly, other recent studies found an increased prevalence of glucose tolerance abnormalities among patients with sCS compared to patients with nonfunctioning adrenal adenomas (15). The prevalence of glucose metabolism abnormalities in patients with monolateral vs bilateral adrenal lesions is the same, even if sCS was more frequent among patients with bilateral disease (18). Insulin sensitivity parameters were reduced in both non-functioning adrenal adenoma or in sCS, compared to healthy controls. There was no difference in terms of insulin sensitivity between the two groups of adrenal lesion patients, but subjects with sCS had a significantly higher prevalence of IGT and a higher area under the curve 
for glucose (19). These data and other studies demonstrate that patients with adrenal incidentaloma, regardless of the functional status, show insulin resistance $(20,21,22,23)$. Moreover, one study found a correlation between adrenal lesion size and insulin resistance (20). Therefore, we could turn the question around and ask whether insulin, a known growth factor, might have a potential role in the development and growth of the adrenal lesions (20). On the other hand, patients with non-functioning adrenal lesions could develop insulin resistance because of a subtle alteration of cortisol secretion dynamics not identifiable as autonomous sCS (22).

Mechanism • Impairment of glucose metabolism in CS patients is due to a combination of several concurrent GC-related effects which directly and indirectly affect glucose homeostasis, mainly through the induction of gluconeogenesis and the disruption of insulin receptor signalling (Fig. 2). Patients with CS have an increased HOMA-index and a reduced insulin sensitivity index regardless of BMI, suggesting that hypercortisolism per se impacts on insulin sensitivity (8). GC excess increases glucose production in the liver by directly inducing the expression of key enzymes for gluconeogenesis (primarily by increasing the transcription of glucose-6-phosphatase); indirectly providing substrates for gluconeogenesis through the stimulation of lipolysis and proteolysis; antagonising the action of insulin; and enhancing the action of different insulin-antagonist hormones, especially glucagon (24).

GCs increase the expression of MAPK phosphatase 3 (MKP3), which in turn activates forkhead box O1 (FOXO1) promoting its translocation from cytosol to nucleus. Activated FOXO1 increases the transcription of the peroxisome proliferator-activated receptor gamma $(\operatorname{PPAR} \gamma)$ co-activator 1 alpha (PGC1 $\alpha)$ and also interacts with PGC1 $\alpha$ to initiate the transcription of genes coding for gluconeogenic enzymes (phosphoenolpyruvate carboxykinase, glucose 6-phosphatase) (25). The mechanisms through which GCs alter hepatic gluconeogenesis and insulin sensitivity also involve crosstalk of the GC receptor (GR) with other signalling pathways. Indeed, an interplay has been found between GR and liver X receptors (LXRs), which are known to heterodimerise with the retinoid $\mathrm{X}$ receptor (RXR) to regulate cholesterol turnover and glucose metabolism. In a recent study, the LXRs/RXR complex reduced the transcriptional activity of GR, since LXR activation was able to reduce dexamethasonestimulated elevation of circulating glucose in rats and suppress dexamethasone-induced mRNA expression of hepatic glucose-6-phosphatase in rats, mice and human hepatoma cells (26). Moreover, the PPAR $\alpha$ signalling pathway, which is required to suppress glucose-stimulated insulin secretion during fasting, has been found to be involved in the dexamethasone-mediated insulin resistance in the liver (27).

GCs also affect glucose metabolism through specific actions on skeletal muscle (Fig. 2). The detrimental effects of GC excess on glucose uptake and glycogen synthesis in the skeletal muscle is due to the interference with the postreceptor signalling pathway of the insulin receptor. Dexamethasone reduces the tyrosine-phosphorylation of insulin receptor substrate (IRS)-1, and consequently the activation of phosphatidylinositol 3 kinase (PI3K) and protein kinase $\mathrm{B}$ (PKB)/AKT, leading to impaired glucose transporter type 4 (GLUT4) migration to the cell surface. GCs also lower glycogen synthase kinase (GSK) phosphorylation and block the ability of insulin to dephosphorylate and activate glycogen synthase, leading to reduced glycogen synthesis (28).

GCs indirectly impair insulin signalling via effects on proteins and lipid metabolism. GC excess is associated with increased protein breakdown, leading to increased concentrations of amino acids. Amino acids interfere with the intracellular insulin pathway by inhibiting IRS tyrosine-phosphorylation and activation of PI3K (29). Hypercortisolism is also associated with increased lipolysis, causing free fatty acid (FFA) elevation, which affects insulin receptor signalling and, consequently, glucose uptake and disposal $(24,30)$. The increased intramyocellar fat and fatty acid metabolites content, consequent to the increased FFA influx into skeletal muscle coupled with decreased mitochondrial fat oxidation, lead to increased serine-phosphorylation of IRS1, via increased activity of serine kinases such as PKC. Serine-phosphorylation of IRS1 impairs its tyrosine phosphorylation by the insulin receptor and thus its activation, leading to the disruption of the insulin signalling cascade (30).

The typical visceral pattern of fat distribution in CS patients leads to increased leptin and reduced apelin levels, which have been associated with insulin resistance $(24,31)$. In mice, plasminogen activator inhibitor 1 (PAI1) expression was upregulated in white adipose tissue by corticosteroids, and transgenic PAI1 deficiency was able to counteract the negative effects of GCs on glucose metabolism, reducing insulin resistance (32).

Chronic hypercortisolism causes pancreatic $\beta$-cell dysfunction (Fig. 2). GC excess leads to impaired uptake and metabolism of glucose in $\beta$ cells by reducing the expression levels of glucose transporter type 2 and 


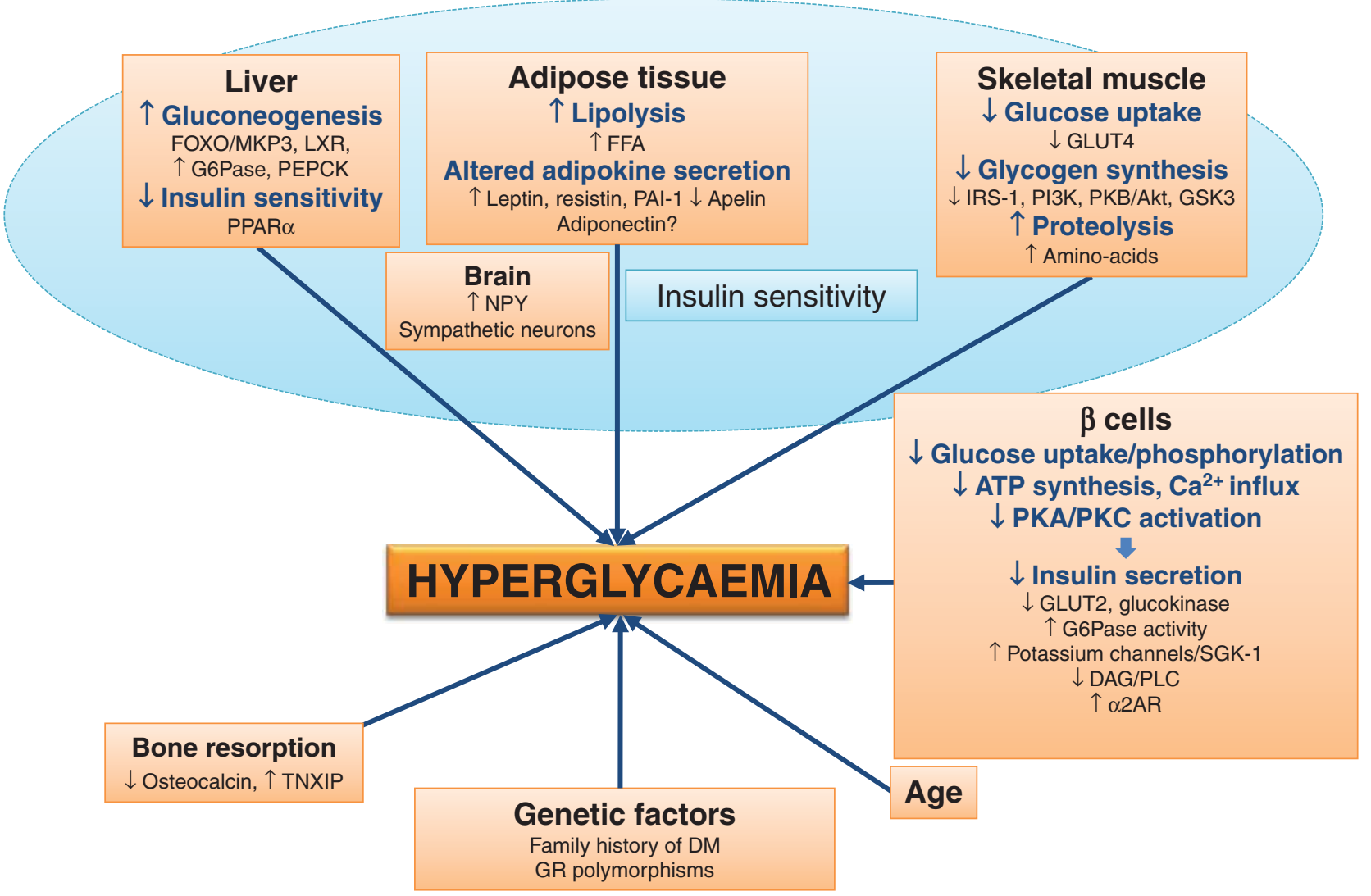

\section{Figure 2}

Hyperglycaemia in Cushing's syndrome. Hyperglycaemia in CS is due to several GC-related actions on the liver, skeletal muscle, adipose tissue and pancreas. GCs induce an increase of gluconeogenic enzymes, via upregulation of the forkhead transcription factor FOXO1 and mitogen activated kinase phosphatase 3 (MKP3) and via cross talk with other signalling pathways such as LXR. They reduce insulin sensitivity in the liver (with the contribution of PPAR $\alpha$ signalling and

GC-associated effects on hypothalamus) and skeletal muscle.

The adipose tissue contributes to the insulin resistance through the deregulation of adipokine secretion and free fatty acid (FFA) release. GCs affect $\beta$-cell function interfering with glucose uptake and $\beta$-oxidation as well as with protein kinase $A /$ protein kinase $C$ (PKA/PKC) activation with a consequent reduction of

glucokinase leading to a decrease in ATP synthesis and calcium influx, resulting ultimately in reduced insulin secretion. Overexpression of the noradrenergic receptor, deregulation of ion channels and inhibition of the DAG-phospholipase $C$ pathway have also been demonstrated to play a role in the GC-mediated alteration of insulin secretion (24). It was also recently reported that insulin secretion. Bone remodelling via reduced osteocalcin and increased thioredoxin-interacting protein 1 (TNXIP) can further contribute to the complex mechanism leading to glucose metabolism impairment. Age and genetic predisposing factors have been shown to be involved as well. G6Pase, glucose6-phosphatase; PEPCK, phosphoenolpyruvate carboxykinase; PPAR $\alpha$, peroxisome proliferator-activated receptor $\alpha$; PAI1, plasminogen activator inhibitor 1; NPY, neuropeptide Y; GLUT4, glucose transporter type 4; IRS1, insulin receptor substrate 1; PI3K, phosphatidylinositol 3 kinases; PKB, protein kinase $B$; GSK3, glycogen synthase kinase3; ATP, adenosine triphosphate; GLUT2, glucose transporter type 2; SGK1, serum/GC regulated kinase 1; DAG, dyacylglycerol; PLC, phospholipase C; $\alpha 2 A R, \alpha 2$ adrenergic receptor; DM, diabetes mellitus; GR, GC receptor.

short-term exposure to GCs reduced the insulinotropic effects of glucagon-like peptide 1 (GLP1) (33). While GCs acutely inhibit insulin secretion, chronically the GC-induced increased insulin resistance leads to hyperinsulinaemia (34). In rats, GCs impact on the mass and function of pancreatic $\alpha$ cells, causing hyperglucagonaemia (35). 
In addition, some data suggest that hypothalamic arcuate nucleus GC signalling modulates hepatic insulin responsiveness via neuropeptide $\mathrm{Y}$ (NPY) and the sympathetic system (36).

The individual sensitivity to GCs can also contribute to the occurrence of glucose metabolism alterations: the beneficial GR polymorphism A3669G is associated with a reduced risk of GC-induced DM regardless of age, sex, BMI, family history of DM and duration of disease (37).

Recent data have also linked glucose homeostasis to bone remodelling in CS, in addition to the detrimental direct effect of GCs on bone. CS patients display low levels of osteocalcin which in turn has been associated with impaired glucose metabolism, insulin resistance and visceral fat (VAT) $(38,39)$. Thioredoxin interacting protein (TXNIP)-1 is upregulated in bone cells by GCs and might contribute to reduced osteocalcin levels. Endogenous CS patients have increased bone expression of TXNIP, which has been associated with high levels of glucose and insulin, increased insulin resistance and decreased insulin sensitivity. The direct link between altered TXNIP, osteocalcin and glucose abnormalities requires further study (40). The intricate interplay between genetic predisposing factors, aging, alteration of insulin sensitivity and $\beta$-cell function contributes to the development, progression and severity of the GC-induced abnormalities in glucose metabolism.

Management $\downarrow$ In endogenous CS, the first step in the management strategy is the treatment of the underlying cause, with the consequent normalisation of cortisol levels, which generally leads to an improvement of the glucose metabolism. The potential benefit of adrenal surgery on the metabolic profile of patients with adrenal adenomas and sCS, in comparison to a more conservative management, is controversial and still a matter of debate, with a preponderance of studies suggesting that patients' glucose profiles and consequently cardiovascular risk would be improved by adrenalectomy (41, 42, 43). However, definitive rapid correction of hypercortisolism in CS is not always easily achievable. The most recently introduced medical therapy for $\mathrm{CD}$, pasireotide, is potentially diabetogenic. Furthermore, glucose metabolism abnormalities can persist after cure.

Insulin sensitizers, such as metformin and thiazolidinediones, are considered as first-line therapy. These can be combined with agents that increase postprandial insulin secretion such as sulphonylureas and meglitinides. The effect of metformin (and possibly thiazolidinediones) on fat tissue and other organ AMP-activated protein kinases
(AMPK) could be beneficial $(44,45)$. Pioglitazone may have a potential negative effect on heart and bone (46). Thiazolidinediones have been demonstrated to have a direct adrenocorticotropic hormone (ACTH)-lowering effect on corticotrophinomas in vitro, but no convincing results arose from clinical trials on patients with CD (47). GLP1 analogues and dipeptidyl peptidase four inhibitors could be helpful in the management of GC-induced diabetes, increasing glucose dependent insulin secretion and reducing glucagon secretion as well as having positive effects on $\beta$-cell mass and function, appetite, adipocyte modulation, fat distribution, hyperlipidaemia, heart and bone $(48,49)$. Incretin-based medications have been suggested for the management of pasireotide-induced hyperglycaemia, since somatostatin receptor inhibition leads to reduced secretion of GLP1, glucose-dependent insulinotropic polypeptide and insulin $(50,51)$. Conventional tailored schemes of treatment with insulin analogues can be required when oral hypoglycaemic agents are not effective (24).

\section{GCs and obesity}

GCs severely affect adipose tissue biology and endocrine function via several mechanisms (Fig. 3). Chronic hypercortisolism determines a redistribution of body fat deposition leading to increased abdominal adiposity, with the related metabolic consequences. Direct and indirect GC effects on the central nervous system that influence eating behaviour can contribute to the obese phenotype of CS patients.

GC effect on appetite - Although excess GCs are generally thought to increase appetite, studies on animals, healthy controls or patients treated with GCs short or long term produced controversial results in terms of appetite and energy intake (52). While in healthy volunteers a modest appetite increase can be shown, in patients the underlying illness, type of steroid medication and duration of exposure can influence appetite, energy intake and body weight changes $(52,53)$. Furthermore, endogenous hypercortisolism can considerably differ from the iatrogenic GC excess in terms of effects on appetite and food intake. CD patients have an increased preference for dietary fat compared to weight-matched and normalweight controls (54). High-dose GC treatment, especially if not associated to high-dose carbohydrate intake, does not necessarily lead to weight or abdominal fat gain in rodents, probably also because of the diabetes-related catabolic effects (55). In humans, the rapid development 


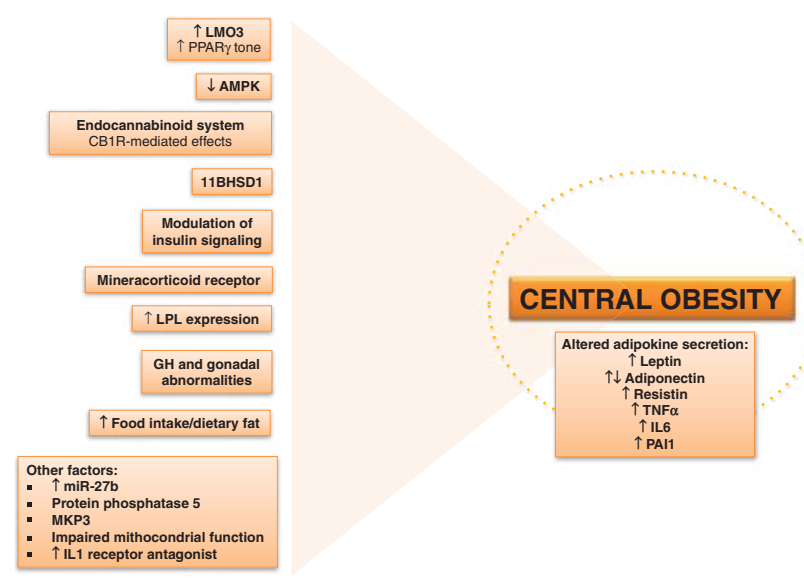

Figure 3

Central obesity in Cushing's syndrome. Fat tissue redistribution in CS leads to central obesity and metabolic complications. Visceral obesity is associated to altered adipokine secretion further contributing to insulin resistance, inflammation and fat accumulation. LMO3, LIM domain only 3; PPAR $\gamma$, peroxisome proliferator-activated receptor $\gamma ; \mathrm{CB} 1 \mathrm{R}$, cannabinoid receptor 1 ; AMPK, AMP-activated protein kinase; 11BHSD1, 11 $\beta$-hydroxysteroid dehydrogenase enzyme; LPL, lipoprotein lipase; mIR27b, microRNA 27b; MKP3, MAP kinase phosphatase 3; TNF $\alpha$, tumour necrosis factor-alpha; IL6, interleukin 6; PAI1, plasminogen activator inhibitor 1; IL1, interleukin 1.

of CS with very high cortisol levels, often due to ectopic ACTH-secreting tumours, can also lead to the lack of the otherwise typical weight gain in CS (56).

In animal models, chronic stress and the related increase in GCs lead to cravings for 'comfort food' (fat and carbohydrates) via a sequence of interconnected amygdala-limbic system-hypothalamic events (57). The resulting increased dopamine levels in the nucleus accumbens may then lead to reduced stress. Some data in humans also support this hypothesis (57). Weight gain would occur as a consequence of a stress-related shift to comfort food, with a redistribution of fat from periphery to the central compartment facilitated by GC in synergy with insulin (57).

Both in vitro (58) and in vivo (44) studies showed that GCs increase hypothalamic endocannabinoids. GCs and cannabinoids have been shown to increase hypothalamic AMPK activity resulting in increased appetite (59). Moreover, GCs have been shown to upregulate the gene expression of orexigenic peptides (NPY and agouti-related peptide) in rat arcuate nucleus also via AMPK (60). The GC effect on hypothalamic AMPK is lacking in cannabinoid receptor 1-knockout $(\mathrm{KO})$ animals, supporting the hypothesis that cannabinoids are involved in the hypothalamic AMPK and possibly the appetite effects of GCs (55).

GC effect on adipose tissue - GCs are crucial for adipocyte differentiation (61) by inducing key adipogenic transcription factors (62) and they are known to regulate $20 \%$ of the adipose expressed genes (63). GCs sensitize preadipocytes to the action of insulin, leading to enhanced adipogenic action (64). GCs alter glucose metabolism and insulin sensitivity in adipocytes and they regulate lipid turnover by modulating the expression of genes involved in lipid storage and mobilization $(65,66)$. VAT is thought to be differentially responsive to GCs than subcutaneous fat (SAT). Indeed, GC binding to tissue homogenates and GR mRNA expression is higher in omental fat than in SAT $(67,68)$. Moreover, GCs were able to induce insulin resistance in human omental but not in subcutaneous adipocytes (69). In humans, GC excess results in increased abdominal VAT deposition and reduced peripheral subcutaneous adipose depots. This can be only partially explained by the reduced lipolysis in central adipose tissue and the increased triglycerides uptake in abdominal adipocytes due to lipoprotein lipase overexpression (70, 71). Several different mechanisms can contribute to determining GC-mediated adipose tissue changes (Fig. 3).

11ß-hydroxysteroid dehydrogenase type 1 activity $\bullet$ Intracellular GC metabolism is regulated by the activity of two isoforms of the 11ß-hydroxysteroid dehydrogenase enzyme, 11BHSD1 and 11BHSD2. 11BHSD1 promotes conversion of inactive cortisone to cortisol, whereas 11BHSD2 inactivates cortisol into cortisone. 11BHSD1 is widely expressed throughout the body, including the liver, visceral fat and SAT (72). Cortisol can reach a GR via several routes: direct binding of cortisol to GR; inactivation of circulating cortisol by 11BHSD2 in the kidney, then reactivation in peripheral tissues by 11BHSD1; and GR-induced local 11BHSD1 expression further amplifying intracellular cortisol availability (Fig. 4, panel A). The importance of excess or lack of locally produced GCs has been studied using global or tissue-specific overexpression or KO of 11BHSD1 (Fig. 4, panels B, C and D). GC treatment of global 11BHSD1-KO animals failed to cause CS. However, rodents with selective deletion of 11BHSD1 in the adipose tissue or in the liver were not protected from increased adiposity, decreased lean mass, glucose intolerance and hyperinsulinaemia or reduced grip strength following GC treatment. These findings would 

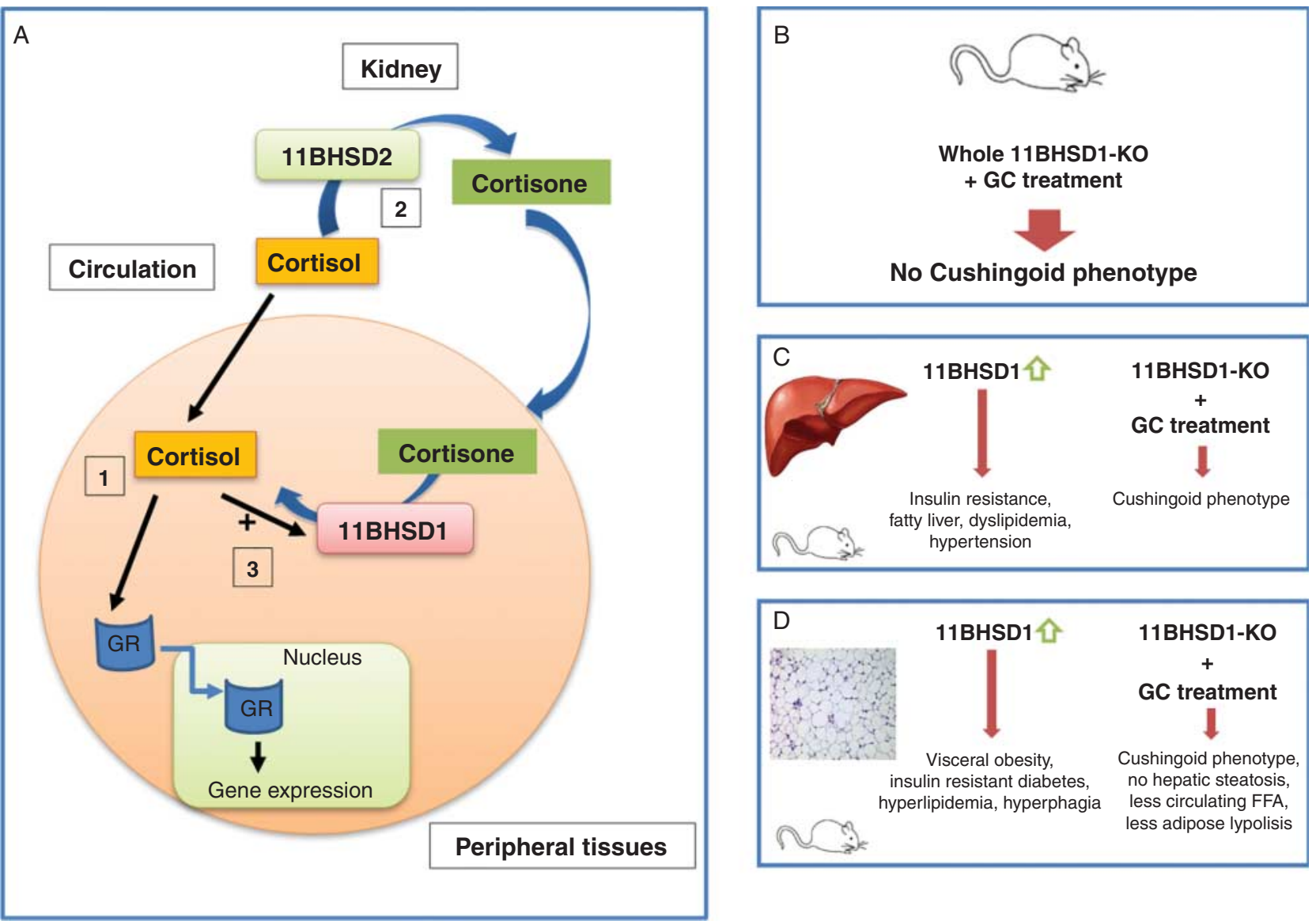

\section{Figure 4}

The $11 \beta$-hydroxysteroid dehydrogenases. Panel A: GC metabolism and tissue availability is regulated by the activity of two isoforms of the $11 \beta$-hydroxysteroid dehydrogenase enzyme 11BHSD1 and 11BHSD2. Cortisol can reach glucocorticoid receptor (GR) via several routes: [1] direct binding of cortisol to GR; [2] inactivation of circulating cortisol by 11BHSD2 in the kidney, then reactivation in peripheral tissues by $11 \mathrm{BHSD} 1$; and

suggest the importance of GC reactivation in tissues other than adipose and liver in the development of the CS phenotype. However, GC-treated adipose-specific 11BHSD1-KO mice were protected from lipid accumulation in the liver, increased circulating FFA and increased expression of lipolytic enzymes in fat tissue but not from increased expression of fatty acid transporters in the liver, suggesting that hepatic FFA uptake is not affected by 11BHSD1 expression in the adipose tissue. Interestingly, liver-specific 11BHSD1-KO did not protect the mice from adverse liver effects, suggesting the importance of 11BHSD1 expression in the adipose tissue in mediating negative metabolic effects on the liver (73). In another
[3] GR-induced local 11BHSD1 expression further amplifying intracellular cortisol availability. Panels B, C, D: Clinical phenotype of mice with transgenic global (B) or tissue specific (C, liver; D, adipose tissue) deficiency of 11BHSD1 after GC treatment or overexpression (green arrow) of 11BHSD1. FFA, free fatty acids; KO, knockout.

study, corticosterone treatment increased 11BHSD1 expression in adipose tissue of mice, and 11BHSD1 knockdown by shRNA attenuated GC-induced lipolysis and ameliorated insulin resistance in adipocytes (74). Adipose tissue-specific overexpression of 11BHSD1 leads to increased corticosterone content in fat tissue and associates to signs of the metabolic syndrome with visceral obesity, worsened by a high-fat diet, pronounced insulinresistant diabetes, hyperlipidaemia and hyperphagia despite hyperleptinaemia (75). The importance of local GC action in the adipose tissue has also been shown in transgenic mice overexpressing 11BHSD2 exclusively in the adipose tissue, as these animals resist weight gain on 
high-fat diet due to reduced fat mass accumulation (76). Similarly, adipose GR deficient mice have been shown to be protected from high-fat diet-induced obesity (77).

Liver-specific 11BHSD1 overexpression resulted in mild insulin resistance (without altered fat depot mass), fatty liver, dyslipidaemia and hypertension. These data would suggest that elevated hepatic expression of 11BHSD1 can be related to the pathogenesis of metabolic syndrome in the absence of obesity, like the metabolically obese but normal-weight individual (78). In humans, the key role of 11BHSD1 in determining Cushingoid features is demonstrated by a unique patient with $\mathrm{CD}$ who did not manifest the characteristic clinical signs, due to a functional defect of 11BHSD1 activity (79). Although 11BHSD1 mRNA is increased in the adipose tissue of obese individuals (80), this does not seem to apply to CS patients. 11BHSD1 mRNA and protein expression of omental adipose tissue is 13-fold higher in obese subjects compared with controls, but no difference was seen between CS patients and normal weight controls (81). The authors speculated that the lack of increase of 11BHSD1 expression in CS patients could be due to the downregulation of the enzyme as a result of long-term chronic cortisol overstimulation, representing a local defensive mechanism of the adipose tissue preventing 11BHSD1 overexpression, which in turn would be responsible for a further cortisol increase.

AMPK activity - Several studies have found that GC tissue specifically influences AMPK activity (Fig. 5). In an animal model of CS, corticosterone treatment inhibited adipose tissue AMPK, which would support the accumulation of lipids in VAT (44). GC-induced adipose AMPK inhibition has also been confirmed in patients with CS who exhibited a 70\% lower AMPK activity in VAT as compared with both non-functioning adrenal adenoma and control patients and was associated with increased mRNA expression of fatty acid synthase. AMPK activity showed a negative correlation to cortisol burden in these patients (45).

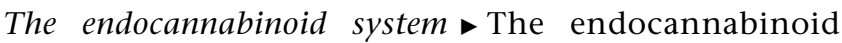
system is also involved in the adverse metabolic features of chronic GC exposure. Scerif et al. (55) showed significant differences in GC-treated WT and cannabinoid receptor type $1 \mathrm{KO}$ mice, and more recently, similar data showed the role of the cannabinoid system in GC-induced changes (82).

The mineralocorticoid receptor $\$ The possibility of GCinduced adipose tissue mineralocorticoid receptor (MR) activation leading to pro-adipogenic effects has been raised. MR expression is increased in the adipose tissue of obese subjects (83) and has been shown to play a crucial role in adipocyte differentiation $(84,85)$. Furthermore, MR blockade was able to reduce the expression of pro-inflammatory and pro-thrombotic factors and to increase the expression of adiponectin in adipose tissue of obese diabetic mice (86) as well as attenuated adipocytes dysfunction and insulin resistance in obese mice (87). On the other hand, in primary cultures of human preadipocytes and adipocytes, GR expression is several 100fold higher than MR. Silencing of GR, but not MR, blocked the pro-adipogenic actions of cortisol. In addition, GR silencing blocked the effects of cortisol on adipokines expression, while MR knockdown only increased leptin expression (88). Moreover, recently, transgenic mice overexpressing MR have been shown to be paradoxically protected from high-fat diet-induced obesity (89).

LIM domain only $3 \bullet$ LIM domain only 3 (LMO3), a proadipogenic factor that is more expressed in VAT than in SAT, could be the link between GCs and VAT changes. LMO3 has been recently demonstrated to be upregulated by GCs, to correlate with 11BHSD1 levels and to promote adipogenesis via increasing PPAR $\gamma$ tone in human VAT (90). As LMO3 is not expressed in rodent visceral tissue, this mechanism could also explain the well-known striking difference in GC-induced visceral adiposity in humans and mice.

Other mechanisms - In mice, GCs have been recently shown to upregulate miR-27b, which inhibits the browning of white adipose tissue, a process which leads the white adipose tissue to express the uncoupling protein UCP1 (as brown adipose tissue) and to dissipate energy. MiR-27b inhibition improved GC-induced central fat accumulation (91). A recent animal model study suggests a role of protein phosphatase 5 (PP5), which is supposed to be a regulator of the transcriptional activity of GR, in adipose tissue distribution. Mice knocked in with a defective form of PP5 had less VAT surrounding gonads and kidneys and smaller adipocytes, probably via a disruption of the GC-related effects on pre-adipocyte differentiation (92). GCs, via FOXO1, increase the expression of MKP3. Mice lacking MKP3 are protected from some GC-related metabolic effects such as weight gain, increased adiposity, liver lipid accumulation and insulin resistance (93). In mice, an impairment of mitochondrial function has been related to increased epididymal adiposity after GC treatment (94). Recent in vitro data showed that 


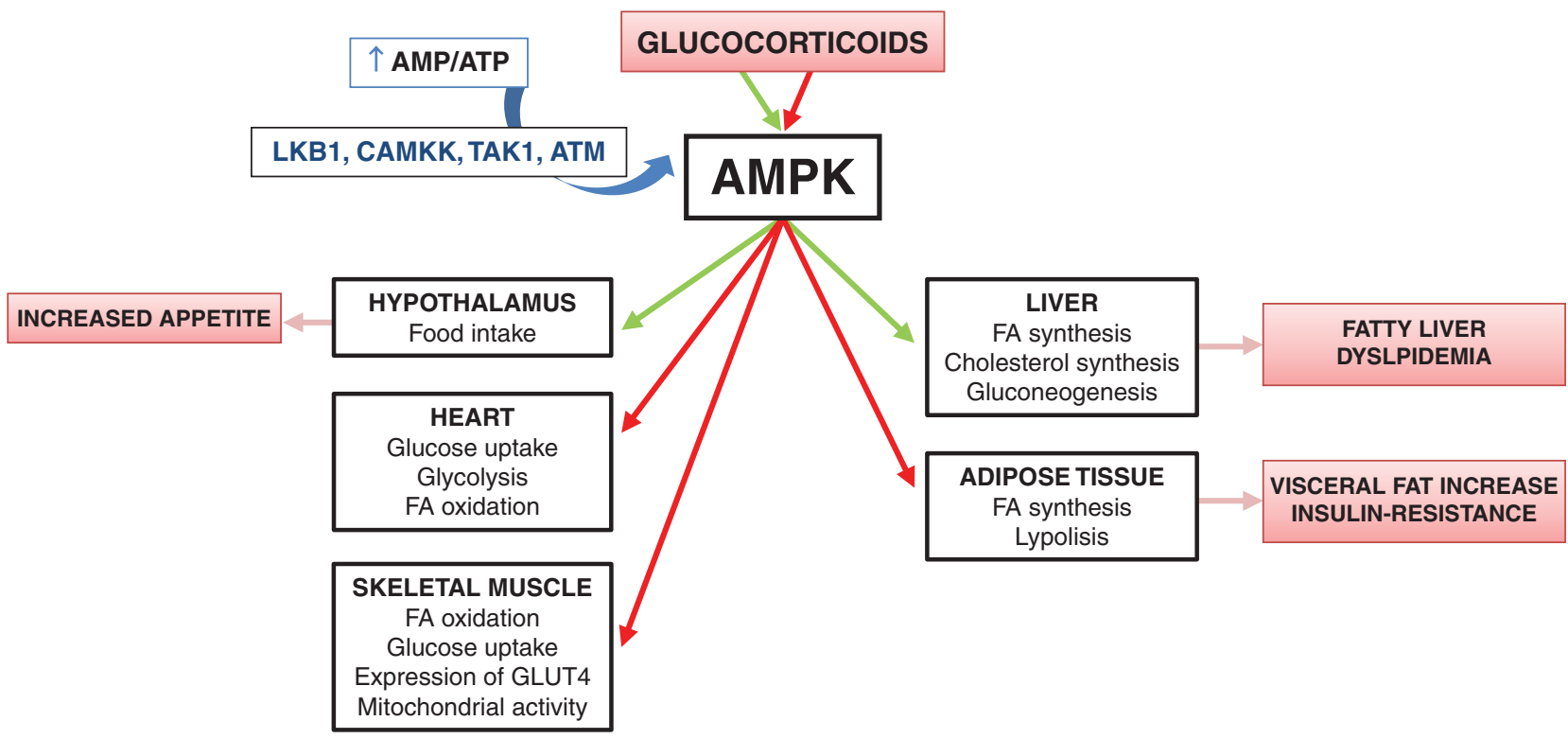

\section{Figure 5}

GCs and AMPK. AMP-activated protein kinase (AMPK), a cellular energy status sensor, is activated by high adenosine monophosphate (AMP)/ATP ratio through phosphorylation (LKB1, CAMKK, TAKI, ATM) and expressed in different tissues that exert several metabolic related actions (black frame boxes). GCs stimulate (green arrow) and inhibit (red arrow) AMPK

dexamethasone induces proliferation, differentiation and basal metabolic activity of human brown adipocytes but inhibits their function under adrenergic stimulation (95).

The adipose tissue in CS patients $~$ Fat distribution shows an increase in VAT and VAT/SAT in CS, and without the normal male to female difference in VAT. Fat distribution correlated with age but not with glucose levels, circulating cortisol, ACTH or lipids (96). In one study, the total body fat of CS patients was found to be associated with increased levels of IL1 receptor antagonist (IL1RA), which decreased significantly after reduction of fat mass following cure. The authors suggested that IL1RA, which binds competitively to the IL1 type I receptor, abolishing the effects of the leptin-induced reduction in food intake, could mediate leptin resistance in CS, thus contributing to body composition change (97). In CS patients, VAT and abdominal SAT, measured by magnetic resonance imaging (MRI), have been found to be higher compared to controls, but no difference has been found in limb subcutaneous adipose tissue between patients and matched controls (98). The same authors also showed that CD patients after a mean of 20 months of remission had expression/activity in hypothalamus, liver and adipose tissue contributing to increased appetite, visceral fat deposition, hepatic steatosis, dyslipidaemia and insulin resistance. GLUT4, glucose transporter type 4; FA, fatty acids; LKB1, liver kinase B1; CAMKK, calmodulin kinase kinase; TAK1, transforming growth factor- $\beta$-activated kinase; ATM, ataxia telangiectasia mutated.

significantly reduced total, abdominal visceral and subcutaneous and bone marrow adipose tissue compared to active disease, although most of them were still overweight or obese (99). Correction of hypercortisolism is generally associated with a reduction of VAT and SAT mass, although adverse metabolic profile and increased cardiovascular risk can persist after remission $(1,100,101)$. Although CS patients experience loss of weight and fat in the short-medium term after remission (102), long-term follow-up demonstrated increased abdominal fat mass compared to age- and gender-matched controls (103). In another study, long-term cured CS patients had total fat mass and trunk fat mass comparable to patients with active disease and higher than gender-, age- and BMImatched healthy controls (104). Similarly, studies on prolonged follow-up of CD children and adolescents reported persistence of increased total body fat, ratio of VAT to SAT and waist circumference $(105,106)$. The effects of exogenous hypercortisolism on body composition can be different from those seen in endogenous CS. A comparison of the body composition of patients cured from endogenous CS with rheumatoid arthritis patients treated with a low-dose of GCs showed that the increase in 
total body fat and trunk fat is higher in endogenous than exogenous CS (107). Recently, it has been shown that patients with CS due to primary pigmented nodular adrenal disease have a typically milder obese phenotype than other forms of CS, even when their cortisol levels are comparable and their CS is not atypical or cyclical (108). The authors speculate that patients with CS due to perturbations of the cAMP/PKA pathway may be less obese because of increased PKA activity and resulting altered downstream regulation of cAMP-related lipogenic and lipolytic proteins (109). The influence of DHEA, the levels of which can be altered in CS, on fat distribution is not clear. Patients with adrenal adenoma and sCS were found to have increased VAT, measured by CT, similarly to patients with overt CS (110).

Ghrelin and adipokines in CS $\diamond$ Patients with active CD have lower ghrelin levels compared to BMI-matched controls, which cannot be explained by increased insulin resistance, as they had similar indices of glucose metabolism. They also showed that ghrelin levels did not correlate with ACTH or cortisol in patients with active CD and did not parallel the reduction of cortisol that shortly follows surgery, suggesting no direct effect of cortisol levels on ghrelin. Cured patients showed an improvement in glucose and lipid homeostasis and increased ghrelin levels, suggesting an indirect effect of cortisol on ghrelin, mediated by the modulation of metabolic signals (111).

GCs, directly or indirectly via the metabolic changes, affect the endocrine activity of adipose tissue. The effects of GC excess on adiponectin levels are controversial. In an animal model of CS, plasma adiponectin levels were significantly higher than those of the WT littermates but mRNA and protein levels were significantly decreased in the adipose tissue. Bilateral adrenalectomy eliminated both their Cushing's phenotype and their increase in plasma adiponectin levels (112). In contrast, in humans, adiponectin levels did not differ between patients and BMI-matched controls (111). In another study, non-obese CS patients had lower adiponectin concentrations compared to non-obese controls, but this difference was not present when comparing obese CS patients and obese controls. This suggests that obesity is crucial when considering adiponectin levels in CS patients (113). Conflicting data have been reported about adiponectin levels before and after resolution of CS $(104,114,115)$.

Leptin levels have been shown to be higher in patients with CS compared to normal weight or BMI-matched controls (115). Leptin does not seem to be acutely affected by the cortisol drop following neurosurgery but it has been found to be decreased in patients after long-term remission (116).

Resistin is significantly higher in female CS patients than in female control subjects and does not significantly change after cure, despite improvement of obesity and metabolic profile (116). TNF $\alpha$ levels are unchanged in CS (115). However, the soluble TNF $\alpha$ receptor 1 is increased in CS compared to BMI-matched controls before and after remission, suggesting a potential contribution of $\mathrm{TNF} \alpha$ pathway to the persistent dysmetabolic features and increased cardiovascular risk observed after cure (104). The same applies to IL6, which is higher in active CS patients and remains increased after cure (104).

Liver steatosis in CS patients $>$ Liver-specific disruption of GR activity leads to reduced hepatic lipid content in animal models (117). Lack of 11BHSD1 decreases hepatic steatosis, but the extent of the contribution of 11BHSD1 expression and activity in the liver to the lipid accumulation is controversial $(73,118,119)$. MKP3 deficiency has been shown to protect mice from GC-induced fatty liver (93).

Non-alcoholic fatty liver disease (NAFLD) is more frequent in people with obesity and diabetes and is considered the liver manifestation of metabolic syndrome. The combined effects of increased lipogenesis and reduced fatty acid oxidation in the liver, increased circulating FFA, VAT accumulation and dysregulation of adipokines can affect the development of hepatic steatosis in CS patients. In one CT-based study, hepatic steatosis was found in $20 \%$ of the CS patients with active disease. There was a significant negative correlation between both liver attenuation and liver/spleen ratio with total abdominal fat area, VAT area, the percentage of VAT and the visceral to SAT ratio (120).

\section{Dyslipidemia in CS}

GCs regulate both lipolytic and adipogenic processes. Different studies investigating the lipid profile of GC excess subjects showed dyslipidaemia in $37-71 \%$ of CS patients $(1,8,100,121)$. Hypercholesterolemia was found in $16-60 \%$ of the CS patients, with increased triglycerides in $7-36 \%$ of cases $(1,8,100,121)$. HDL levels can be reduced, but some authors did not report decreased HDL cholesterol or high total cholesterol/HDL and LDL/HDL ratios in active CS patients $(8,99)$. Improvements of dyslipidaemia after cure/remission occur, but an adverse lipid profile can persist in approximately $30 \%$ of the patients (1), probably due to GC-induced modifications on 
adipose tissue. Patients with adrenal adenoma and sCS have been shown to have significantly increased cholesterol and triglyceride levels and decreased HDL cholesterol levels compared to controls, contributing to the increase in cardiovascular risk (121). However, in a subgroup of sCS patients no significant improvement was observed after adrenalectomy (122). Moreover, in another cohort of adrenal adenoma patients, the occurrence of dyslipidaemia was associated with the presence of impaired glucose metabolism rather than to the subtle cortisol hypersecretion per se (123). Patients undergoing long-term treatment with GCs causing typical Cushingoid fat deposition were demonstrated to have higher LDL and lower HDL cholesterol compared to GC-treated patients without the typical pattern of fat distribution (124). In contrast, another study addressing the effects of exogenous GC treatment showed no association between GC use and dyslipidaemia, and unusually, an increased HDL cholesterol level was found in patients treated with GCs who were above 60 years old (125).

Mechanism \ GCs increase the expression of adipose triglyceride lipase and hormone sensitive lipase (HSL), which are in charge of stored lipid breakdown in mature adipocytes, causing an increase in circulating FFA levels (126). GCs also stimulate lipolysis by increasing cAMP levels, with consequent activation of PKA, which can serin-phosphorylate HSL and perilipin. Perilipin facilitates HSL translocation and activity $(65,126,127)$. GCs can also directly and indirectly affect cAMP levels and, consequently, lipolysis, by decreasing the expression of phosphodiesterase PDE3b, an enzyme involved in cAMP breakdown, and by impairing the insulin dependent activation of PDE3b, resulting in reduced cAMP degradation $(65,126)$. Lipolytic effects of GCs can also be related to the modulation of responsiveness to other hormones such as catecholamines and GH $(70,126)$.

While the lipolytic actions are associated with shortterm exposure to GCs, the pro-adipogenic effects become prominent in chronic hypercortisolism. GCs increase the expression and activity of lipoprotein lipase, which is required to hydrolyse triacylglycerols circulating in the blood within the VLDL or chylomicrons, promoting uptake and storage in the adipose tissue $(128,129,130)$. Therefore, in adipose tissue the two processes can occur at the same time. Mature adipocytes release FFA via the action of triglyceride lipase and HSL, while GC-induced differentiation of pre-adipocytes leads to adipocyte accumulation. In addition, via the increased circulating FFAs, ectopic storage of lipids in liver and skeletal muscle is increased (131). Increased liver lipogenesis then leads to increased secretion of VLDL, which becomes a further source of lipid storage in the adipose tissue (132).

Modifying factors, such as diet, can contribute to the balance of pro-adipogenic vs lipolytic effects. GCs increase dietary fat intake and induce neo-lipogenesis from substrates like glucose. GCs were also shown to inhibit AMPK activity in visceral adipose tissue leading to increased lipogenesis and fat storage. CS patients have $70 \%$ lower AMPK activity in visceral adipose tissue compared to control subjects with a consequent increase of fatty acid synthase expression $(44,45)$. In transgenic mice, the impact of selective adipose- or liver-specific 11BHSD1 overexpression on lipid levels has been discussed previously. The N363S GR polymorphism was reported to be associated with an enhanced sensitivity to GCs and with increased BMI and LDL cholesterol levels, as well as an increased risk of cardiovascular disease (133). GH deficiency combined with altered gonadal function can contribute to lipid abnormalities.

Management $~$ There are no guidelines specifically addressing how to treat dyslipidaemia in CS. However, in these patients, an aggressive management of lipid alterations is recommended due to the increased cardiovascular risk. Experimental treatment with 11BHSD1 inhibitors improved triglyceridaemia by reducing hepatic VLDL secretion and increased liver fatty acid oxidation. A 28-day treatment with INCB013739, a selective inhibitor of 11BHSD1, was shown to improve insulin sensitivity and lowered total and LDL cholesterol in patients with type 2 DM $(134,135)$.

The side effects of cortisol-lowering drugs on lipid levels should be considered: ketoconazole reduces total, intermediate density and LDL cholesterol and apoB levels by around 25\% (136); mitotane increases total cholesterol by $68 \%$, inducing an elevation of LDL cholesterol and apoB (137). In patients treated with ketoconazole, the use of pravastatin and rosuvastatin instead of other statins has been suggested to reduce the risk of myotoxicity, since these lipidlowering drugs are not metabolised by CYP3A4 which is inhibited by the treatment with ketoconazole (138).

\section{GCs and GH abnormalities}

A normal GC milieu is needed for normal growth as GCs are important modulators of $\mathrm{GH}$ secretion and action and play an essential role in the differentiation as well as the function of somatotrophs (139). Both lack and excess of GCs lead to reduced height and lower GH levels. 
Low GH levels of infants with congenital secondary hypoadrenalism can be restored with GC replacement $(140,141)$. GCs can also restore GH response to provocative stimuli in Addison's disease (142). While acute exposure to GCs stimulates the GH/IGF1 axis, chronic excess has a profound negative effect. Exercise-induced GC response is coupled with increased GH levels and acute GC administration is followed by an increase in $\mathrm{GH}$ $(143,144)$. Prolonged GC excess, however, is a well-known negative regulator of GH secretion. Short stature and delayed linear growth are typical features of paediatric CS, and slowed growth is common in children undergoing long-term/high-dose GC therapy. Spontaneous catch-up growth is unlikely even after successful treatment in paediatric CS (145). A significant proportion of paediatric CD patients cured by surgery alone or in combination with radiotherapy shows abnormalities of GH secretion after long-term cure, which are more common and persistent if other pituitary hormone deficits are present (146).

There is evidence supporting the negative impact of hypercortisolism on GH secretion in adult patients as well. In a small study, $\mathrm{GH}$ response to pyridostigmine/GHRH was found to be impaired in 14 CS patients. The GH/IGF1 axis recovered at 6 months after successful treatment in half of the patients, at 12 months in two and at 18 months in one patient. GH axis recovery was more common in patients in whom there was recovery of the hypothalamicpituitary-adrenal (HPA) axis as well (147). Data from the KIMS database showed that GH deficient (GHD) patients with a previous history of $\mathrm{CD}$ had the same characteristics in terms of body composition and lipid levels but a higher prevalence of diabetes, hypertension, bone fractures and lower BMD, as well as a more impaired quality of life compared to GHD patients with other aetiologies (148). As GCs significantly impact on adiposity and BMI, which in turn can affect GH secretion, BMI alone can only partially explain GH impairment in CS patients (149).

In $\mathrm{CD}$ patients, $\mathrm{GH}$ impairment can also be the consequence of surgical treatment and/or radiotherapy. GHD is present in adult CD patients after long-term remission even if treated only with transsphenoidal neurosurgery. Male gender and the duration of disease were the most relevant predictors of GH/IGF1 axis disturbances after cure of CD (150).

Patients with adrenal adenomas and subclinical hypercortisolism had a reduced $\mathrm{GH}$ secretion reserve compared to patients with non-functioning adrenal adenomas after adjusting for age and BMI. GH secretion improved after recovery (151).
Mechanism $~-$ The stimulation of GH secretion induced by an acute increase of GCs could be playing a part in physical or emotional stress-induced GH increase (139). One of the suggested mechanisms involves a steroid hormone-induced GTP binding protein (dexamethasoneinduced Ras protein, dexras), which activates ERK1/2 and leads to phosphorylation of the E-twenty-six transcription factor family member ELK1. ELK1 has binding sites on the GH promoter (139). On the other hand, longterm GC excess can alter GH secretion dynamics via increasing somatostatinergic tone (152). Chronic hypercortisolism has multiple deleterious effects on growth, and some of them are uncoupled from GH/IGF1 secretion impairment. Indeed, GCs (i) impair gonadal function, mainly via inhibiting gonadotropin secretion and GnRH transcription, but also by interfering with testicular function and sex hormone-binding globulin synthesis in the liver; (ii) exert catabolic actions on bone and muscle; (iii) negatively affect calcium/vitamin D metabolism; and (iv) exert direct inhibitory effects on the growth plate $(153,154)$.

Management $\downarrow$ Early treatment with GH after cure of CS is an important consideration. Studying 13 paediatric patients with GHD following successful CS treatment, hGH therapy resulted in better height SDS $(-1.3)$ and somewhat improved BMI (155), suggesting that early treatment of GHD is recommended to achieve optimal growth, while excess adiposity can be a persistent longterm complication (155). These results were in line with previous findings (156). Several studies compared adult $\mathrm{CD}$ and non-functioning pituitary adenoma (NFPA) patients treated with GH. Quality of life improved significantly with a 6-month GH treatment in cured CD patients (148). A 3-year follow-up study of GH-treated CD $(n=160)$ and NFPA $(n=879)$ patients found that the prevalence of metabolic syndrome, which was not significantly different at baseline, was significantly higher in CD than NFPA patients (23.4 vs $9.2 \%$ ). The prevalence of diabetes, cardio- and cerebrovascular disease was higher in patients with a history of CD compared to NFPA patients, suggesting that GHD CD subjects are predisposed to adverse metabolic features and increased cardiovascular risk (157). Comparing the effect of GH treatment on lean body mass in cured CD and NFPA patients, NFPA patients showed significant improvement while $\mathrm{CD}$ patients did not, suggesting that GHD patients previously treated for $\mathrm{CD}$ could be resistant to the protein anabolic effect of GH even years after remission (158). 


\section{Heart and vasculature in CS}

CS patients have increased cardiovascular morbidity and mortality due to several closely related factors such as hypertension, metabolic changes, coagulopathy and specific GC-related alterations of the heart and vasculature (Fig. 6).

Hypertension - Hypertension has been reported in $55-85 \%$ of the CS patients and has been associated with disease duration. Hypertension has been shown to persist after cure in $24-56 \%$ of the cases, especially when patients are older at diagnosis or have a longer history of hypercortisolism or a longer duration of untreated hypertension (4).

Several mechanisms have been suggested to play a role in causing hypertension in CS: mineralocorticoid activity of cortisol; activation of renin-angiotensin system; enhancement of cardiovascular reactivity to vasoconstrictors; increased $\beta$-adrenergic receptor sensitivity to catecholamines; suppression of the vasodilatory system; increased cardiac output, total peripheral resistance and

\section{GLUCOCORTICOIDS}

\begin{tabular}{|c|c|c|c|}
\hline \multicolumn{2}{|c|}{$\begin{array}{cc}\text { BRAIN } & \text { SKELETAL MUSCLE } \\
\text { † Food intake } & \downarrow \text { Insulin sensitivity } \\
& \downarrow \text { Glucose uptake } \\
& \downarrow \text { Glycogen synthesis } \\
& \uparrow \text { Lipolysis and } \beta \text {-oxidation } \\
& \uparrow \text { Proteolysis }\end{array}$} & $\begin{array}{c}\text { ADIPOSE TISSUE } \\
\uparrow \downarrow \text { Insulin sensitivity } \\
\uparrow \text { Adipogenesis } \\
\uparrow \text { Lipolysis } \uparrow \text { FFA } \\
\text { Altered adipokines secretion }\end{array}$ & $\begin{array}{c}\text { LIVER } \\
\downarrow \text { Insulin sensitivity } \\
\uparrow \text { Gluconeogenesis } \\
\uparrow \text { Lipogenesis }\end{array}$ \\
\hline \multicolumn{4}{|c|}{ METABOLIC SYNDROME } \\
\hline \multicolumn{4}{|r|}{ 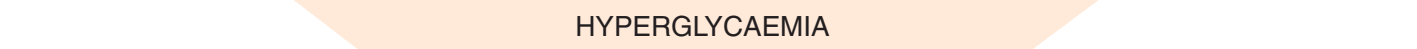 } \\
\hline \multicolumn{4}{|c|}{ 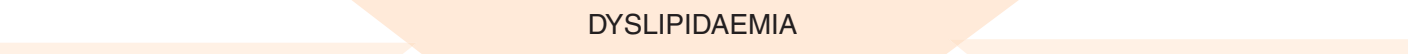 } \\
\hline \multirow[t]{2}{*}{ ATHEROSCLERC } & \multicolumn{2}{|c|}{$\begin{array}{l}\text { CENTRAL OBESITY } \\
\text { HYPERTENSION }\end{array}$} & $\begin{array}{c}\text { STRUCTURAL \& FUNCTIONAL } \\
\text { CARDIAC } \\
\text { CHANGES }\end{array}$ \\
\hline & $\begin{array}{l}\text { VASCULAR REMODELLING } \\
\text { ENDOTHELIAL } \\
\text { DYSFUNCTION }\end{array}$ & \multicolumn{2}{|c|}{$\begin{array}{c}\text { ALTERED } \\
\text { AUTONOMIC } \\
\text { REGULATION of the } \\
\text { HEART }\end{array}$} \\
\hline \\
\hline
\end{tabular}

\section{INCREASED CARDIOVASCULAR RISK}

\section{Figure 6}

Cardiovascular risk in Cushing's syndrome. Metabolic syndrome is extremely common in CS. GCs induce hyperglycaemia by increasing hepatic gluconeogenesis and disrupting the insulin signalling in the liver, skeletal muscle and adipose tissue with a consequent decrease of peripheral use and disposal of glucose. Central fat accumulation is coupled with deregulation of adipokine secretion and facilitated by GC-related increased appetite, enhanced adipogenesis and altered lipid storage.
Hyperlipidaemia, a major cardiovascular risk factor, is strictly associated to the increased mobilization of free fatty acids (FFA) from the adipose tissue and increased hepatic lipogenesis. The CS patient with obesity, diabetes mellitus, dyslipidaemia, hypertension, procoagulant phenotype and severe structural and functional alterations of the heart and vessels is the prototype of a patient with increased cardiovascular risk. 
renovascular resistance; insulin resistance; and sleep apnoea $(159,160)$.

GCs can induce hepatic synthesis of angiotensinogen, increase angiotensin II receptor type 1 concentration in the brain and peripheral tissue and enhance both angiotensin II-stimulated inositol phosphate-3 production in vascular smooth muscle cells and its central actions $(159,161)$. GC-induced increase of erythropoietin contributes to vasoconstriction and therefore hypertension (162). Endothelin has been found to be increased in CS patients (163). This increase could be related to the GC excess-induced endothelial damage and increased vascular permeability, causing endothelin hypersecretion in the circulation with the consequent permissive effect on the atherogenic and pressor action of endothelin. GCs can downregulate the plasma membrane sodium-calcium exchanger as well (164). CS patients have been shown to have a blunted vascular and renal response to pharmacological doses of atrial natriuretic peptide compared to normal controls and hypertensive subjects (165). Impaired production of vasodilators including prostaglandins, prostacyclins and compounds of the kallikrein-kinin system might also contribute to CS hypertension (160). Moreover, cortisol-induced hypertension is characterised by reduced activity of the nitric oxide pathway (166). GCs have been shown to downregulate nitric oxide synthase cofactor tetrahydrobiopterin (BH4) and GTP cyclohydrolase 1 , the rate-limiting enzyme in the production of $\mathrm{BH} 4$, thus contributing to the reduced endothelium-dependent relaxation (167).

Vascular damage - Vascular remodelling and increased vascular oxidative stress play a major role in CS-associated cardiovascular comorbidities. The cross-sectional media area of subcutaneous small resistance arteries was significantly greater in CS compared to hypertensive patients and controls, while the media to lumen ratio was greater in hypertensive and CS patients compared to controls (168). MR activation by GCs can mediate vascular damage, since mineralocorticoids have growth promoting and profibrotic activities, which lead to remodelling and fibrosis of small vessels (169). CS patients with metabolic, cardiovascular and bone complications have increased oxidative stress markers, such as 15-F2t-IsoP and TBX2, compared to CS patients without complications or to control subjects. Vitamin E levels, a suggested marker of the antioxidant status, were significantly lower in CS patients compared to controls. These findings would suggest that excess GCs induce pro-oxidative processes which, in combination with the metabolic comorbidities, lead to a vicious loop of worsening oxidant-antioxidant balance and increased cardiovascular morbidity and mortality (170).

Patients with CS have been demonstrated to have increased carotid intima media thickness (IMT) $(1,100)$ and increased endothelial dysfunction, as shown by studies reporting impaired flow mediated vasodilatation $(171,172)$. Atherosclerotic plaques are more prevalent in $\mathrm{CD}$ patients than in the control population even after long-term remission and correlation with insulin resistance and central adiposity $(1,173)$. IMT correlated with waist-hip-ratio and fasting glucose, but no correlation was found with the cortisol levels (173).

Increased coronary calcifications and non-calcified coronary plaque volume, quantified by multidetector CT coronary angiogram scan, have been found in patients with active CS (3). Increased prevalence of coronary artery disease persists even after long-term remission of CS, since more coronary calcification and non-calcified plaques were found in cured CS patients than in age- and gender-matched controls (174). Coronary flow reserve is more commonly reduced in CS patients, compared to matched controls, and correlates negatively to urinary free cortisol (175).

Several studies found patients with adrenal adenomas and sCS to experience cardiovascular events more frequently than patients with non-functioning adrenal adenomas, and this increased prevalence of cardiovascular disease was found to be associated with subclinical hypercortisolism $(16,176,177)$.

Inflammatory markers, such as soluble tumour necrosis factor receptor (sTNFR1), IL6, IL8, IL1b and glutathione peroxidase (GPx), which is involved in preventing cells from oxidative damage, have been found to be increased in CS patients. sTNFR1 was found to be the strongest predictor of IMT in CS along with GPx, IL1b and cortisol after a lowdose dexamethasone suppression test (178). In another cohort of patients with active or cured CS, sTNFR1 has been found to correlate with the Agatston score, being a predictor of coronary calcifications (179).

Endothelin, homocysteine, VEGF, osteoprotegerin and cell adhesion molecules (such as soluble intercellular adhesion molecule-1 and vascular cell adhesion molecule-1) have been found to be increased in CS patients with active disease, while taurine, a suggested protective factor, is decreased. These parameters all improved or normalized after successful therapy $(180,181,182,183)$.

Cardiac morphology $\$ Cardiac morphology changes have been associated with chronic hypercortisolism, and 
specifically with the length of exposure to GCs, and functional modifications have been also reported.

Echocardiography in CS patients showed that up to $70 \%$ of the patients with active CS presented abnormal left ventricular (LV) mass parameters: $42 \%$ presented concentric hypertrophy and 23\% concentric remodelling. Major indices of systolic and diastolic functions were reported to be normal. After remission of hypercortisolism, LV mass parameters improved considerably but did not normalize completely (184). In a previous paper, echocardiographic assessment of $\mathrm{CD}$ patients revealed $\mathrm{LV}$ hypertrophy and diastolic dysfunction as well as subclinical LV systolic dysfunction, which reversed after remission (185). Using cardiac MRI, subclinical systolic biventricular and left atrial (LA) systolic dysfunction associated with increased LV mass was found in CS patients compared to the controls. Remarkably, the study showed that the effective treatment of hypercortisolism improved the systolic performance of both ventricles and LA, reduced LV mass and LV wall thickness and led to the regression of the concentric LV remodelling pattern. The treatment-related decrease in LV mass was independently associated with changes in glucose metabolism and BMI. Moreover, on the basis of the absence of gadolinium enhancement of the myocardium, the study ruled out dense replacement myocardial fibrosis in uncomplicated CS (186). However, a previous study showed increased myocardial fibrosis, assessed by echocardiography, in CS patients compared to healthy controls and hypertensive patients (187). On ECG, changes in the QT interval have been found to be a specific feature of CD patients and to correlate with hypercortisolaemia regardless of other risk factors suggesting a cardiotoxic effect of cortisol excess per se (188). Altered autonomic cardiac regulation can contribute to the overall increased cardiovascular risk. Several studies found abnormalities in cardiovascular autonomic regulation in CS patients, as suggested by reduced heart rate variability $(189,190)$.

Patients with adrenal adenomas and sCS have been found to have increased LV mass compared to healthy controls and subjects harbouring non-functioning adrenal adenomas (191). Significant structural and functional modifications of the heart and vasculature can also be detected in paediatric CS patients (192).

Management $\downarrow$ In patients with endogenous CS, the identification and removal of the source of hypercortisolism lead to an improvement of hypertension in a significant proportion of patients $(193,194)$. The same seems to apply to patients with sCS in which adrenalectomy has been shown to be more effective than medical treatment (195).

However, in order to prevent cardiovascular events, a tailored antihypertensive treatment is often required before surgery, or when the surgical approach is unsuccessful, or when the disease is cyclical, or in combination with cortisol-lowering medical treatment, or when hypertension persists despite the surgical or pharmacological control of hypercortisolism. Indeed, some medium/longterm follow-up studies of CS patients in remission showed a persistence of high blood pressure and a still increased risk of morbidity and mortality due to the increased cardiovascular risk $(1,100,196)$. This risk is more consistent for cardio- and cerebrovascular events than for heart failure (196). While the length of exposure to cortisol excess has been clearly linked to the persistence of high blood pressure, the role of age at onset of hypercortisolism is not clear.

The management of hypertension in CS patients cannot leave out of consideration the mechanisms through which the GC excess determines the increased blood pressure and cardiovascular damage. Angiotensinconverting-enzyme inhibitors and angiotensin receptor blockers, with their cardioprotective effects, have been recently proposed as a first-line treatment to which calcium-antagonists, known to delay atherosclerosis and prevent stroke, and/or mineralocorticoid receptor antagonists can be added according to the severity of the condition and the presence of hypokalaemia (197). In the proposed treatment algorithm, $\alpha$-blockers could be considered as the further next step. The use of thiazides and $\beta$-blockers should be limited to selected cases after the appropriate dose titration of the previously mentioned agents due to their potential metabolic side-effects (197).

With regard to the effects of cortisol-lowering drugs on hypertension, it has been shown that ketoconazole ameliorates blood pressure in more than $80 \%$ of the cases (198) and mitotane in 63\% (199). Mifepristone was able to improve diastolic blood pressure and/or reduce the number of hypertensive drugs in $52 \%$ of the patients (200), but in other studies some patients experienced a worsening of hypertension and hypokalaemia (201). Metyrapone treatment can be also associated with increased blood pressure and hypokalaemia due to the rise in steroids with mineralocorticoid activity. Pasireotide, alone or in combination with cabergoline and ketoconazole, has been demonstrated to improve hypertension $(202,203)$. Retinoic acid has been demonstrated to be effective in reducing blood pressure as well (204). The new compound LCI699, which acts by inhibiting 


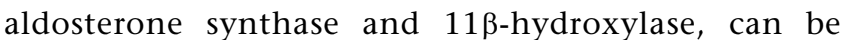
beneficial in terms of blood pressure (205), but, similarly to metyrapone, the increased mineralocorticoids can lead to a worsening of hypertension.

\section{Muscle in CS}

Around $60 \%$ of the CS patients experience proximal muscle atrophy and weakness, which have been reported to be more frequent in men (6). CS patients have reduced lean mass, due to muscle loss of the limbs, compared to obese subjects with the same total fat mass (206). Respiratory muscle strength does not seem to be affected in CS (207). Muscle damage can persist both short- and long-term after cure. Indeed, the reduced muscle area in the arms showed no relevant improvement 6 months after successful treatment (102). MRI body composition assessment of CD patients 20 months after remission showed that total and limb skeletal muscle is actually reduced compared to active disease (99). The authors speculated that this could be due to the GC replacement therapy after cure since it inversely correlated with muscle mass. They also found that the difference in patients' muscle mass between active disease and remission disappeared when disregarding post-menopausal women, suggesting a role of the oestrogen deprivation as well (99). Furthermore, a long-term follow-up study demonstrated that patients with CS had reduced limb skeletal muscle mass, but similar total lean body mass, compared to age- and gendermatched controls (103).

Muscle fibre conduction is also altered in CS patients. Creatinine kinase, plasma myoglobin and muscle fibre conduction velocity were reduced in CS patients compared to healthy age-, sex- and BMI-matched controls, and creatinine kinase and muscle fibre conduction velocity correlated with disease duration (208). However, electromyography alterations typical of classical myopathy are rarely seen in the early stage of disease (209).

GC-induced changes in muscle are evident after a few days of GC administration. In healthy volunteers $8 \mathrm{mg}$ dexamethasone administration for 7 days resulted in a decrease in the muscle fibre cross-sectional area, loss of myosin and a reduction in power (210). Short-term effects, more common in intensive care units, generally involve proximal and distal muscles. The type, dose and duration of steroid treatment determine the occurrence and severity of myopathy. Fluorinated steroids (such as dexamethasone or betamethasone) cause myopathy more frequently than non-fluorinated agents (such as prednisolone and hydrocortisone) (211). The reason why fluorinated agents are more frequently associated to myopathy is not clear, but it could be speculated that different GCs exert different genomic and non-genomic actions and impact on different signalling pathways, having different anti-inflammatory or anti-proliferative effects, with consequent different metabolic outcomes (212). Chronic GC excess generally has a more prominent effect on the proximal muscles (213). Interestingly, in aging subjects (without CS) muscle mass loss and decreased function were not associated to circulating or urinary cortisol, but muscle strength correlated with quadriceps 11BHSD1 mRNA expression, supporting the importance of local cortisol conversion and tissue-specific cortisol metabolism rather than overall circulating levels in determining negative effects of GCs (214).

Mechanism $~$ GC-induced muscle atrophy affects mainly fast-twitch or type II fibres with less or no impact observed in type I, the more oxidative type of fibres $(211,215)$. Histological features of GC-related myopathy are nonspecific atrophy of type IIb muscle fibres, the absence of inflammatory infiltrate, variations in fibre size with centrally placed nuclei and, rarely, signs of muscle necrosis (215). GCs reduce skeletal muscle mass both by inhibiting protein synthesis and by increasing the rate of protein degradation (Fig. 7). GCs inhibit the transport of amino acids into the muscle and interfere with the stimulatory action of insulin, IGF1 and amino acids on AKT and mTOR and, consequently, on the phosphorylation of eIF4Ebinding protein 1 and the ribosomal protein S6 kinase 1, which are known to play a crucial role in the protein synthesis machinery $(211,216)$. A recent study demonstrated that caveolin 1 (CAV1) is a critical regulator of muscle homeostasis through the modulation of the insulin-signalling pathway. GC response elements have been identified in the promoter of the CAV1 gene, and dexamethasone treatment reduced CAV1 protein and mRNA expression with a concomitant reduction in insulin receptor alpha (IR $\alpha$ ) and IRS1 levels in C2C12 myotubes. In addition, CAV1 knockdown decreased the protein levels of IR $\alpha$ and IRS1, and overexpression of CAV1 prevented the dexamethasone-induced decrease in IR $\alpha$ and IRS1 proteins (217). GCs promote proteolytic degradation of myofibrillar and extracellular matrix proteins by inducing the expression of components of the ubiquitin and proteasome system; activating the lysosomal system, as suggested by the presence of markers of autophagy in the muscle of GC-treated animals, and stimulating the calcium-mediated proteolytic system (218). GC-induced FOXO and C/EBP $\beta$ trigger the expressions of genes involved in muscle protein 


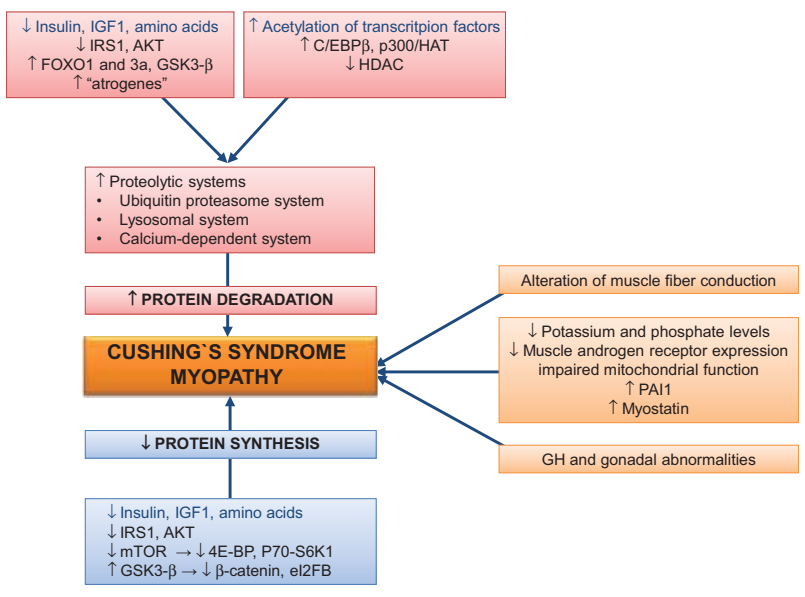

\section{Figure 7}

Cushing's syndrome myopathy. GCs induce muscle loss by impairing the anabolic action of insulin, IGF1 and amino acids. GCs increase protein degradation via the disruption of PI3K/AKT pathway and the stimulation of transcription factors (FOXO1 and $3 a$, GSK3- $\beta$ ) leading to the transcription of genes involved in muscle atrophy (atrogenes). GCs reduce protein synthesis via the inhibition of the transport of amino acids in the muscle and the inhibition of the stimulatory action of IGF1 and amino acids on mTOR with the consequent decreased activity of 4E-BP1 and S6K1. GSK3- $\beta$ can also contribute to the reduced protein synthesis through decreased $\beta$-catenin and elF-2B. GC-induced protein acetylation leads to increased proteolysis. The deleterious effect of $\mathrm{GH}$ and gonadal axis impairment contribute to the muscle disease as well. IRS1, insulin receptor substrate 1; FOXO1 and 3a, forkhead box protein 01 and 3a; GSK3- $\beta$, glycogen synthase kinase 3 beta; C/EBP $\beta$, CCAAT/enhancer binding protein beta; HDAC, histone deacetylases; mTOR, mammalian target of rapamycin; P70-S6K1, P70S6 kinase 1; 4E-BP, elF4E-binding protein 1; PAI1, plasminogen activator inhibitor 1.

breakdown via the ubiquitin proteasome system and autophagy. A GC-induced increase of p300/HAT and a decrease of histone deacetylases expression and activity can lead to hyperacetylation and consequent activation of transcription factors involved in protein degradation pathways. Moreover, GC-related proteasome-dependent degradation of other factors, such as $\mathrm{MyoD}$ and myogenin that are involved in anabolic pathways, can further contribute to muscle loss. Stimulation of GSK3 by GCs may also be involved in the inhibition of protein synthesis through decreased $\beta$-catenin and eIF-2B and increased muscle proteolysis $(211,218)$. Moreover, GCs inhibit the production of IGF1 in muscle, which contributes to muscle development and integrity by increasing protein synthesis and myogenesis while decreasing proteolysis and apoptosis $(211,219)$. GCs stimulate myostatin, an inhibitory growth factor that downregulates protein synthesis, proliferation and differentiation of muscle satellite cells, precursors of skeletal muscle cells $(220,221)$. GCs can indirectly affect muscle physiology through downregulating gonadal function and reducing the expression of the androgen receptor in skeletal muscle (219). Other factors have also been thought to be implicated in GC-associated myopathy, such as the GC effects on potassium and phosphate levels and mitochondrial function $(209,222)$. A recent study showed that mice lacking PAI1 are protected from GC-induced muscle atrophy (32).

In humans, however, the mechanism leading to muscle loss may not be exactly the same as in rodents, and the precise contribution of anti-anabolic and catabolic GC effects to myopathy needs to be clarified. In contrast with animal studies, GCs did not regulate the expression of proteolytic genes in CS patient muscle. No change was found in mRNA levels for cathepsin D (a lysosomal proteinase), m-calpain $\left(\mathrm{a} \mathrm{Ca}^{2+}\right.$-activated proteinase), ubiquitin, $14-\mathrm{kDa}$ ubiquitin-activating enzyme E2 and $20 \mathrm{~S}$ proteasome subunits (which are critical components of the ubiquitin-proteasome proteolytic process) in the skeletal muscle of CS patients. The authors speculated that this could be due to the occurrence of adaptive regulatory mechanisms, consequent to chronic hypercortisolism, preventing sustained increased protein breakdown to avoid continuous rapid muscle wasting (223).

Intramuscular adipose tissue is linked to an adverse metabolic profile. In animal models, GCs induced an increase of intramuscular adipose tissue through the induction of pre-adipocyte differentiation mediated by inhibition of IL4 (224). In contrast, intramuscular adipose tissue is not increased in CS patients compared to BMImatched controls (98).

Management $>$ The treatment of GC-associated myopathy should start with the correction of the underlying cause of endogenous hypercortisolism. In case of iatrogenic hypercortisolism, the discontinuation or dose titration of the steroid drug, or the replacement with a non-fluorinated agent (such as prednisolone), should be considered. Experimental treatments such as IGF1, branched-chain amino acids, creatinine, testosterone, nandrolone and DHEA and glutamine have been proposed (215). Only a few studies have demonstrated that aerobic and resistance exercises are effective in attenuating GC-induced muscle atrophy (211). 


\section{Summary}

The diagnosis and management of endogenous CS is one of the most challenging and could be one of the most rewarding tasks of an endocrine team. Exogenous GCs are hugely effective treatments for a number of severe diseases, while their use in a high percentage of cases inevitably will lead to iatrogenic CS. In this context, efforts should focus on synthetic GCs devoid of negative metabolic effects while retaining anti-inflammatory properties. The elucidation of the mechanisms involved in metabolic complications of excess GCs may lead to solutions for prevention and treatment and provides exciting challenges for both basic and clinical science. Many questions remain open: What is the molecular mechanism underlying GC-induced changes on the morphology and deteriorated function of the heart? What are the pathophysiological mechanisms involved in the persistence of increased morbidity and mortality in CS patients even after long-term remission? What is the molecular basis of the different actions of synthetic GCs? What is the exact relevance of GC action on other hormonal axis alterations and their contributions on metabolic changes. Comparative studies are required to examine the cardiometabolic consequences in exogenous vs endogenous hypercortisolism. The effectiveness of specific drug combinations to control hypertension and reduce cardiovascular risk in hypercortisolism needs to be further studied.

\section{Declaration of interest}

The authors declare that there is no conflict of interest that could be perceived as prejudicing the impartiality of the review.

\section{Funding}

This research did not receive any specific grant from any funding agency in the public, commercial or not-for-profit sector.

\footnotetext{
Acknowledgements

We are very grateful for the critical reading by Prof. Ashley Grossman and language correction by Júlia Heckenast.

This paper forms part of a special issue of European Journal of Endocrinology on Cushing's syndrome. This article is adapted from work presented at the IMPROCUSH-1: Improving Outcome of Cushing's Syndrome symposium, 12-14 October 2014. The meeting was supported by the European Science Foundation, Deutsche Forschungsgemeinschaft, Carl Friedrich von Siemens Stiftung, European Neuroendocrine Association and the Deutsche Gesellschaft für Endokrinologie. The opinions or views expressed in this special issue are those of the authors, and do not necessarily reflect the opinions or recommendations of the European Science Foundation, Deutsche Forschungsgemeinschaft, Carl Friedrich von Siemens Stiftung, European Neuroendocrine Association and the Deutsche Gesellschaft fur Endokrinologie.
}

\section{References}

1 Colao A, Pivonello R, Spiezia S, Faggiano A, Ferone D, Filippella M, Marzullo P, Cerbone G, Siciliani M \& Lombardi G. Persistence of increased cardiovascular risk in patients with Cushing's disease after five years of successful cure. Journal of Clinical Endocrinology and Metabolism 199984 2664-2672. (doi:10.1210/jcem.84.8.5896)

2 Etxabe J \& Vazquez JA. Morbidity and mortality in Cushing's disease: an epidemiological approach. Clinical Endocrinology 199440 479-484. (doi:10.1111/j.1365-2265.1994.tb02486.x)

3 Neary NM, Booker OJ, Abel BS, Matta JR, Muldoon N, Sinaii N, Pettigrew RI, Nieman LK \& Gharib AM. Hypercortisolism is associated with increased coronary arterial atherosclerosis: analysis of noninvasive coronary angiography using multidetector computerized tomography. Journal of Clinical Endocrinology and Metabolism 201398 2045-2052. (doi:10.1210/jc.2012-3754)

4 Feelders RA, Pulgar SJ, Kempel A \& Pereira AM. The burden of Cushing's disease: clinical and health-related quality of life aspects. European Journal of Endocrinology 2012 167 311-326. (doi:10.1530/EJE11-1095)

5 Resmini E, Minuto F, Colao A \& Ferone D. Secondary diabetes associated with principal endocrinopathies: the impact of new treatment modalities. Acta Diabetologica 200946 85-95. (doi:10.1007/ s00592-009-0112-9)

6 Pecori Giraldi F, Moro M, Cavagnini F \& Study Group on the Hypothalamo-Pituitary-Adrenal Axis of the Italian Society of Endocrinology . Gender-related differences in the presentation and course of Cushing's disease. Journal of Clinical Endocrinology and Metabolism 200388 1554-1558. (doi:10.1210/jc.2002-021518)

7 Giordano C, Guarnotta V, Pivonello R, Amato MC, Simeoli C, Ciresi A, Cozzolino A \& Colao A. Is diabetes in Cushing's syndrome only a consequence of hypercortisolism? European Journal of Endocrinology 2014170 311-319. (doi:10.1530/EJE-13-0754)

8 Mancini T, Kola B, Mantero F, Boscaro M \& Arnaldi G. High cardiovascular risk in patients with Cushing's syndrome according to 1999 WHO/ISH guidelines. Clinical Endocrinology 200461 768-777. (doi:10.1111/j.1365-2265.2004.02168.x)

9 Boscaro M \& Arnaldi G. Approach to the patient with possible Cushing's syndrome. Journal of Clinical Endocrinology and Metabolism 200994 3121-3131. (doi:10.1210/jc.2009-0612)

10 Valassi E, Santos A, Yaneva M, Toth M, Strasburger CJ, Chanson P, Wass JA, Chabre O, Pfeifer M, Feelders RA et al. The European Registry on Cushing's syndrome: 2-year experience. Baseline demographic and clinical characteristics. European Journal of Endocrinology 2011165 383-392. (doi:10.1530/EJE-11-0272)

11 Shimon I. Screening for Cushing's syndrome: is it worthwhile? Pituitary 201518 201-205. (doi:10.1007/s11102-015-0634-9)

12 Tabarin A \& Perez P. Pros and cons of screening for occult Cushing syndrome. Nature Reviews. Endocrinology $20117445-455$. (doi:10.1038/nrendo.2011.51)

13 Terzolo M, Reimondo G, Chiodini I, Castello R, Giordano R, Ciccarelli E, Limone P, Crivellaro C, Martinelli I, Montini M et al. Screening of Cushing's syndrome in outpatients with type 2 diabetes: results of a prospective multicentric study in Italy. Journal of Clinical Endocrinology and Metabolism 201297 3467-3475. (doi:10.1210/jc. 2012-1323)

14 Giordano R, Guaraldi F, Berardelli R, Karamouzis I, D'Angelo V, Marinazzo E, Picu A, Ghigo E \& Arvat E. Glucose metabolism in patients with subclinical Cushing's syndrome. Endocrine 201241 415-423. (doi:10.1007/s12020-012-9628-9)

15 Di Dalmazi G, Pasquali R, Beuschlein F \& Reincke M. Subclinical Hypercortisolism: A State, A Syndrome, Or A Disease? European Journal of Endocrinology 2015 173. (doi:10.1530/ EJE-15-0272)

16 Di Dalmazi G, Vicennati V, Rinaldi E, Morselli-Labate AM, Giampalma E, Mosconi C, Pagotto U \& Pasquali R. Progressively 
increased patterns of subclinical cortisol hypersecretion in adrenal incidentalomas differently predict major metabolic and cardiovascular outcomes: a large cross-sectional study. European Journal of Endocrinology 2012166 669-677. (doi:10.1530/EJE-11-1039)

17 Kim BY, Chun AR, Kim KJ, Jung CH, Kang SK, Mok JO \& Kim CH. Clinical characteristics and metabolic features of patients with adrenal incidentalomas with or without subclinical Cushing's syndrome. Endocrinology and Metabolism 201429 457-463. (doi:10.3803/EnM. 2014.29.4.457)

18 Vassilatou E, Vryonidou A, Ioannidis D, Paschou SA, Panagou M \& Tzavara I. Bilateral adrenal incidentalomas differ from unilateral adrenal incidentalomas in subclinical cortisol hypersecretion but not in potential clinical implications. European Journal of Endocrinology 2014171 37-45. (doi:10.1530/EJE-13-0848)

19 Ivovic M, Marina LV, Vujovic S, Tancic-Gajic M, Stojanovic M, Radonjic NV, Gajic M, Soldatovic I \& Micic D. Nondiabetic patients with either subclinical Cushing's or nonfunctional adrenal incidentalomas have lower insulin sensitivity than healthy controls: clinical implications. Metabolism: Clinical and Experimental 201362 786-792. (doi:10.1016/j.metabol.2012.12.006)

20 Muscogiuri G, Sorice GP, Prioletta A, Mezza T, Cipolla C, Salomone E, Giaccari A, Pontecorvi A \& Della Casa S. The size of adrenal incidentalomas correlates with insulin resistance. Is there a causeeffect relationship? Clinical Endocrinology 201174 300-305. (doi:10.1111/j.1365-2265.2010.03928.x)

21 Reincke M, Fassnacht M, Vath S, Mora P \& Allolio B. Adrenal incidentalomas: a manifestation of the metabolic syndrome? Endocrine Research 199622 757-761.

22 Androulakis II, Kaltsas GA, Kollias GE, Markou AC, Gouli AK, Thomas DA, Alexandraki KI, Papamichael CM, Hadjidakis DJ \& Piaditis GP. Patients with apparently nonfunctioning adrenal incidentalomas may be at increased cardiovascular risk due to excessive cortisol secretion. Journal of Clinical Endocrinology and Metabolism 201499 2754-2762. (doi:10.1210/jc.2013-4064)

23 Peppa M, Boutati E, Koliaki C, Papaefstathiou N, Garoflos E, Economopoulos T, Hadjidakis D \& Raptis SA. Insulin resistance and metabolic syndrome in patients with nonfunctioning adrenal incidentalomas: a cause-effect relationship? Metabolism: Clinical and Experimental 201059 1435-1441. (doi:10.1016/j.metabol.2010.01.007)

24 Mazziotti G, Gazzaruso C \& Giustina A. Diabetes in Cushing syndrome: basic and clinical aspects. Trends in Endocrinology and Metabolism 201122 499-506. (doi:10.1016/j.tem.2011.09.001)

25 Wu Z, Jiao P, Huang X, Feng B, Feng Y, Yang S, Hwang P, Du J, Nie Y, Xiao G \& Xu H. MAPK phosphatase-3 promotes hepatic gluconeogenesis through dephosphorylation of forkhead box $\mathrm{O} 1$ in mice. Journal of Clinical Investigation 2010120 3901-3911. (doi:10.1172/ JCI43250)

26 Nader N, Ng SS, Wang Y, Abel BS, Chrousos GP \& Kino T. Liver x receptors regulate the transcriptional activity of the glucocorticoid receptor: implications for the carbohydrate metabolism. PLOS ONE 20127 e26751. (doi:10.1371/journal.pone.0026751)

27 Bernal-Mizrachi C, Weng S, Feng C, Finck BN, Knutsen RH, Leone TC, Coleman T, Mecham RP, Kelly DP \& Semenkovich CF. Dexamethasone induction of hypertension and diabetes is PPAR- $\alpha$ dependent in LDL receptor-null mice. Nature Medicine 20039 1069-1075. (doi:10.1038/nm898)

28 Ruzzin J, Wagman AS \& Jensen J. Glucocorticoid-induced insulin resistance in skeletal muscles: defects in insulin signalling and the effects of a selective glycogen synthase kinase-3 inhibitor. Diabetologia 200548 2119-2130. (doi:10.1007/s00125-005-1886-0)

29 Patti ME, Brambilla E, Luzi L, Landaker EJ \& Kahn CR. Bidirectional modulation of insulin action by amino acids. Journal of Clinical Investigation 1998101 1519-1529. (doi:10.1172/JCI1326)

30 Abdul-Ghani MA \& DeFronzo RA. Pathogenesis of insulin resistance in skeletal muscle. Journal of Biomedicine \& Biotechnology 20102010 476279. (doi:10.1155/2010/476279)
31 Kershaw EE \& Flier JS. Adipose tissue as an endocrine organ. Journal of Clinical Endocrinology and Metabolism 200489 2548-2556. (doi:10.1210/jc.2004-0395)

32 Tamura Y, Kawao N, Yano M, Okada K, Okumoto K, Chiba Y, Matsuo O \& Kaji $\mathrm{H}$. Role of plasminogen activator inhibitor-1 in glucocorticoid-induced diabetes and osteopenia in mice. Diabetes 201564 2194-2206. (doi:10.2337/db14-1192)

33 Hansen KB, Vilsboll T, Bagger JI, Holst JJ \& Knop FK. Reduced glucose tolerance and insulin resistance induced by steroid treatment, relative physical inactivity, and high-calorie diet impairs the incretin effect in healthy subjects. Journal of Clinical Endocrinology and Metabolism 2010 95 3309-3317. (doi:10.1210/jc.2010-0119)

34 van Raalte DH, Nofrate V, Bunck MC, van Iersel T, Elassaiss Schaap J, Nassander UK, Heine RJ, Mari A, Dokter WH \& Diamant M. Acute and 2-week exposure to prednisolone impair different aspects of $\beta$-cell function in healthy men. European Journal of Endocrinology 2010162 729-735. (doi:10.1530/EJE-09-1034)

35 Rafacho A, Goncalves-Neto LM, Santos-Silva JC, Alonso-Magdalena P, Merino B, Taboga SR, Carneiro EM, Boschero AC, Nadal A \& Quesada I. Pancreatic $\alpha$-cell dysfunction contributes to the disruption of glucose homeostasis and compensatory insulin hypersecretion in glucocorticoid-treated rats. PLOS ONE 20149 e93531. (doi:10.1371/journal. pone.0093531)

36 Yi CX, Foppen E, Abplanalp W, Gao Y, Alkemade A, la Fleur SE, Serlie MJ, Fliers E, Buijs RM, Tschop MH et al. Glucocorticoid signaling in the arcuate nucleus modulates hepatic insulin sensitivity. Diabetes 201261 339-345. (doi:10.2337/db11-1239)

37 Trementino L, Appolloni G, Concettoni C, Cardinaletti M, Boscaro M $\&$ Arnaldi G. Association of glucocorticoid receptor polymorphism A3669G with decreased risk of developing diabetes in patients with Cushing's syndrome. European Journal of Endocrinology 2012166 35-42. (doi:10.1530/EJE-11-0722)

38 Godang K, Ueland T \& Bollerslev J. Decreased bone area, bone mineral content, formative markers, and increased bone resorptive markers in endogenous Cushing's syndrome. European Journal of Endocrinology 1999141 126-131. (doi:10.1530/eje.0.1410126)

39 Wei J \& Karsenty G. An overview of the metabolic functions of osteocalcin. Reviews in Endocrine \& Metabolic Disorders, 2015. (doi:10.1007/s11154-014-9307-7)

40 Lekva T, Bollerslev J, Sahraoui A, Scholz H, Boyum H, Evang JA, Godang K, Aukrust P \& Ueland T. Thioredoxin interacting protein is a potential regulator of glucose and energy homeostasis in endogenous Cushing's syndrome. PLOS ONE 20138 e64247. (doi:10.1371/journal. pone.0064247)

41 De Leo M, Cozzolino A, Colao A \& Pivonello R. Subclinical Cushing's syndrome. Best Practice \& Research. Clinical Endocrinology \& Metabolism 201226 497-505. (doi:10.1016/j.beem.2012.02.001)

42 Iacobone M, Citton M, Viel G, Boetto R, Bonadio I, Mondi I, Tropea S, Nitti D \& Favia G. Adrenalectomy may improve cardiovascular and metabolic impairment and ameliorate quality of life in patients with adrenal incidentalomas and subclinical Cushing's syndrome. Surgery 2012152 991-997. (doi:10.1016/j.surg.2012.08.054)

43 Perysinakis I, Marakaki C, Avlonitis S, Katseli A, Vassilatou E, Papanastasiou L, Piaditis G \& Zografos GN. Laparoscopic adrenalectomy in patients with subclinical Cushing syndrome. Surgical Endoscopy 201327 2145-2148. (doi:10.1007/s00464-012-2730-5)

44 Christ-Crain M, Kola B, Lolli F, Fekete C, Seboek D, Wittmann G, Feltrin D, Igreja SC, Ajodha S, Harvey-White J et al. AMP-activated protein kinase mediates glucocorticoid-induced metabolic changes: a novel mechanism in Cushing's syndrome. FASEB Journal 200822 1672-1683. (doi:10.1096/fj.07-094144)

45 Kola B, Christ-Crain M, Lolli F, Arnaldi G, Giacchetti G, Boscaro M, Grossman AB \& Korbonits M. Changes in adenosine 5'-monophosphate-activated protein kinase as a mechanism of visceral obesity in Cushing's syndrome. Journal of Clinical Endocrinology and Metabolism 200893 4969-4973. (doi:10.1210/jc.2008-1297) 
46 Bortolini M, Wright MB, Bopst M \& Balas B. Examining the safety of PPAR agonists - current trends and future prospects. Expert Opinion on Drug Safety 201312 65-79. (doi:10.1517/14740338.2013.741585)

47 Ambrosi B, Dall'Asta C, Cannavo S, Libe R, Vigo T, Epaminonda P, Chiodini I, Ferrero S, Trimarchi F, Arosio M et al. Effects of chronic administration of PPAR- $\gamma$ ligand rosiglitazone in Cushing's disease. European Journal of Endocrinology 2004151 173-178. (doi:10.1530/eje. $0.1510173)$

48 Chon S, Riveline JP, Blondeau B \& Gautier JF. Incretin-based therapy and pancreatic $\beta$ cells. Diabetes \& Metabolism 201440 411-422. (doi:10.1016/j.diabet.2014.05.003)

49 Avogaro A, Vigili de Kreutzenberg S \& Fadini GP. Cardiovascular actions of GLP-1 and incretin-based pharmacotherapy. Current Diabetes Reports 201414 483. (doi:10.1007/s11892-014-0483-3)

50 Colao A, De Block C, Gaztambide MS, Kumar S, Seufert J \& Casanueva FF. Managing hyperglycemia in patients with Cushing's disease treated with pasireotide: medical expert recommendations. Pituitary 201417 180-186. (doi:10.1007/s11102-013-0483-3)

51 Reznik Y, Bertherat J, Borson-Chazot F, Brue T, Chanson P, CortetRudelli C, Delemer B, Tabarin A, Bisot-Locard S \& Verges B. Management of hyperglycaemia in Cushing's disease: experts' proposals on the use of pasireotide. Diabetes \& Metabolism 201339 34-41. (doi:10.1016/j.diabet.2012.10.005)

52 Berthon BS, MacDonald-Wicks LK \& Wood LG. A systematic review of the effect of oral glucocorticoids on energy intake, appetite, and body weight in humans. Nutrition Research 201434 179-190. (doi:10.1016/j. nutres.2013.12.006)

53 Tataranni PA, Larson DE, Snitker S, Young JB, Flatt JP \& Ravussin E. Effects of glucocorticoids on energy metabolism and food intake in humans. American Journal of Physiology 1996271 E317-E325.

54 Castonguay TW. Glucocorticoids as modulators in the control of feeding. Brain Research Bulletin 199127 423-428. (doi:10.1016/03619230(91)90136-8)

55 Scerif M, Fuzesi T, Thomas JD, Kola B, Grossman AB, Fekete C \& Korbonits M. CB1 receptor mediates the effects of glucocorticoids on AMPK activity in the hypothalamus. Journal of Endocrinology 2013219 79-88. (doi:10.1530/JOE-13-0192)

56 Terzolo M, Reimondo G, Ali A, Bovio S, Daffara F, Paccotti P \& Angeli A. Ectopic ACTH syndrome: molecular bases and clinical heterogeneity. Annals of Oncology 200112 (Suppl 2) S83-S87. (doi:10.1093/annonc/12.suppl_2.S83)

57 Dallman MF, Pecoraro NC \& la Fleur SE. Chronic stress and comfort foods: self-medication and abdominal obesity. Brain, Behavior, and Immunity 200519 275-280. (doi:10.1016/j.bbi.2004.11.004)

58 Di S, Malcher-Lopes R, Halmos KC \& Tasker JG. Nongenomic glucocorticoid inhibition via endocannabinoid release in the hypothalamus: a fast feedback mechanism. Journal of Neuroscience 200323 4850-4857.

59 Kahn BB, Alquier T, Carling D \& Hardie DG. AMP-activated protein kinase: ancient energy gauge provides clues to modern understanding of metabolism. Cell Metabolism 20051 15-25. (doi:10.1016/j.cmet. 2004.12.003)

60 Shimizu H, Arima H, Watanabe M, Goto M, Banno R, Sato I, Ozaki N, Nagasaki H \& Oiso Y. Glucocorticoids increase neuropeptide Y and agouti-related peptide gene expression via adenosine monophosphate-activated protein kinase signaling in the arcuate nucleus of rats. Endocrinology 2008149 4544-4553. (doi:10.1210/en.2008-0229)

61 Hauner H, Entenmann G, Wabitsch M, Gaillard D, Ailhaud G, Negrel R $\&$ Pfeiffer EF. Promoting effect of glucocorticoids on the differentiation of human adipocyte precursor cells cultured in a chemically defined medium. Journal of Clinical Investigation 198984 1663-1670. (doi:10.1172/JCI114345)

62 Tomlinson JJ, Boudreau A, Wu D, Atlas E \& Hache RJ. Modulation of early human preadipocyte differentiation by glucocorticoids. Endocrinology 2006147 5284-5293. (doi:10.1210/en.2006-0267)
63 Lee MJ, Gong DW, Burkey BF \& Fried SK. Pathways regulated by glucocorticoids in omental and subcutaneous human adipose tissues: a microarray study. American Journal of Physiology. Endocrinology and Metabolism 2011300 E571-E580. (doi:10.1152/ajpendo.00231.2010)

64 Tomlinson JJ, Boudreau A, Wu D, Abdou Salem H, Carrigan A, Gagnon A, Mears AJ, Sorisky A, Atlas E \& Hache RJ. Insulin sensitization of human preadipocytes through glucocorticoid hormone induction of forkhead transcription factors. Molecular Endocrinology 201024 104-113. (doi:10.1210/me.2009-0091)

65 Peckett AJ, Wright DC \& Riddell MC. The effects of glucocorticoids on adipose tissue lipid metabolism. Metabolism: Clinical and Experimental 201160 1500-1510. (doi:10.1016/j.metabol.2011.06.012)

66 Ayala-Sumuano JT, Velez-delValle C, Beltran-Langarica A, MarschMoreno M, Hernandez-Mosqueira C \& Kuri-Harcuch W. Glucocorticoid paradoxically recruits adipose progenitors and impairs lipid homeostasis and glucose transport in mature adipocytes. Scientific Reports 20133 2573. (doi:10.1038/srep02573)

67 Veilleux A, Laberge PY, Morency J, Noel S, Luu-The V \& Tchernof A. Expression of genes related to glucocorticoid action in human subcutaneous and omental adipose tissue. Journal of Steroid Biochemistry and Molecular Biology 2010122 28-34. (doi:10.1016/j.jsbmb.2010.02.024)

68 Rebuffe-Scrive M, Bronnegard M, Nilsson A, Eldh J, Gustafsson JA \& Bjorntorp P. Steroid hormone receptors in human adipose tissues. Journal of Clinical Endocrinology and Metabolism 199071 1215-1219. (doi:10.1210/jcem-71-5-1215)

69 Hazlehurst JM, Gathercole LL, Nasiri M, Armstrong MJ, Borrows S, Yu J, Wagenmakers AJ, Stewart PM \& Tomlinson JW. Glucocorticoids fail to cause insulin resistance in human subcutaneous adipose tissue in vivo. Journal of Clinical Endocrinology and Metabolism 201398 1631-1640. (doi:10.1210/jc.2012-3523)

70 Macfarlane DP, Forbes S \& Walker BR. Glucocorticoids and fatty acid metabolism in humans: fuelling fat redistribution in the metabolic syndrome. Journal of Endocrinology 2008197 189-204. (doi:10.1677/ JOE-08-0054)

71 Geer EB, Islam J \& Buettner C. Mechanisms of glucocorticoid-induced insulin resistance: focus on adipose tissue function and lipid metabolism. Endocrinology and Metabolism Clinics of North America 201443 75-102. (doi:10.1016/j.ecl.2013.10.005)

72 Tomlinson JW, Walker EA, Bujalska IJ, Draper N, Lavery GG, Cooper MS, Hewison M \& Stewart PM. 11ß-hydroxysteroid dehydrogenase type 1: a tissue-specific regulator of glucocorticoid response. Endocrine Reviews 200425 831-866. (doi:10.1210/er.2003-0031)

73 Morgan SA, McCabe EL, Gathercole LL, Hassan-Smith ZK, Larner DP, Bujalska IJ, Stewart PM, Tomlinson JW \& Lavery GG. 11ß-HSD1 is the major regulator of the tissue-specific effects of circulating glucocorticoid excess. PNAS 2014111 E2482-E2491. (doi:10.1073/pnas. 1323681111)

74 Wang Y, Yan C, Liu L, Wang W, Du H, Fan W, Lutfy K, Jiang M, Friedman TC \& Liu Y. 11ß-hydroxysteroid dehydrogenase type 1 shRNA ameliorates glucocorticoid-induced insulin resistance and lipolysis in mouse abdominal adipose tissue. American Journal of Physiology. Endocrinology and Metabolism 2015308 E84-E95. (doi:10.1152/ajpendo.00205.2014)

75 Masuzaki H, Paterson J, Shinyama H, Morton NM, Mullins JJ, Seckl JR \& Flier JS. A transgenic model of visceral obesity and the metabolic syndrome. Science 2001294 2166-2170. (doi:10.1126/science. 1066285)

76 Kershaw EE, Morton NM, Dhillon H, Ramage L, Seckl JR \& Flier JS. Adipocyte-specific glucocorticoid inactivation protects against dietinduced obesity. Diabetes 200554 1023-1031. (doi:10.2337/diabetes. 54.4.1023)

77 de Kloet AD, Krause EG, Solomon MB, Flak JN, Scott KA, Kim DH, Myers B, Ulrich-Lai YM, Woods SC, Seeley RJ et al. Adipocyte glucocorticoid receptors mediate fat-to-brain signaling. Psychoneuroendocrinology 201556 110-119. (doi:10.1016/j.psyneuen.2015. 03.008) 
78 Paterson JM, Morton NM, Fievet C, Kenyon CJ, Holmes MC, Staels B, Seckl JR \& Mullins JJ. Metabolic syndrome without obesity: hepatic overexpression of 11ß-hydroxysteroid dehydrogenase type 1 in transgenic mice. PNAS 2004101 7088-7093. (doi:10.1073/pnas. 0305524101)

79 Tomlinson JW, Draper N, Mackie J, Johnson AP, Holder G, Wood P \& Stewart PM. Absence of Cushingoid phenotype in a patient with Cushing's disease due to defective cortisone to cortisol conversion. Journal of Clinical Endocrinology and Metabolism 200287 57-62. (doi:10.1210/jcem.87.1.8189)

80 Paulmyer-Lacroix O, Boullu S, Oliver C, Alessi MC \& Grino M. Expression of the mRNA coding for 11ß-hydroxysteroid dehydrogenase type 1 in adipose tissue from obese patients: an in situ hybridization study. Journal of Clinical Endocrinology and Metabolism 200287 2701-2705. (doi:10.1210/jcem.87.6.8614)

81 Mariniello B, Ronconi V, Rilli S, Bernante P, Boscaro M, Mantero F \& Giacchetti G. Adipose tissue 11ß-hydroxysteroid dehydrogenase type 1 expression in obesity and Cushing's syndrome. European Journal of Endocrinology 2006155 435-441. (doi:10.1530/eje.1.02228)

82 Bowles NP, Karatsoreos IN, Li X, Vemuri VK, Wood JA, Li Z, Tamashiro KL, Schwartz GJ, Makriyannis AM, Kunos G et al. A peripheral endocannabinoid mechanism contributes to glucocorticoid-mediated metabolic syndrome. PNAS 2015112 285-290. (doi:10.1073/pnas.1421420112)

83 Hirata A, Maeda N, Nakatsuji H, Hiuge-Shimizu A, Okada T, Funahashi T \& Shimomura I. Contribution of glucocorticoidmineralocorticoid receptor pathway on the obesity-related adipocyte dysfunction. Biochemical and Biophysical Research Communications 2012419 182-187. (doi:10.1016/j.bbrc.2012.01.139)

84 Caprio M, Feve B, Claes A, Viengchareun S, Lombes M \& Zennaro MC. Pivotal role of the mineralocorticoid receptor in corticosteroidinduced adipogenesis. FASEB Journal 200721 2185-2194. (doi:10.1096/fj.06-7970com)

85 Hoppmann J, Perwitz N, Meier B, Fasshauer M, Hadaschik D, Lehnert $\mathrm{H} \&$ Klein J. The balance between gluco- and mineralocorticoid action critically determines inflammatory adipocyte responses. Journal of Endocrinology 2010204 153-164. (doi:10.1677/ JOE-09-0292)

86 Guo C, Ricchiuti V, Lian BQ, Yao TM, Coutinho P, Romero JR, Li J, Williams GH \& Adler GK. Mineralocorticoid receptor blockade reverses obesity-related changes in expression of adiponectin, peroxisome proliferator-activated receptor- $\gamma$, and proinflammatory adipokines. Circulation 2008117 2253-2261. (doi:10.1161/CIRCULATIONAHA.107.748640)

87 Hirata A, Maeda N, Hiuge A, Hibuse T, Fujita K, Okada T, Kihara S, Funahashi T \& Shimomura I. Blockade of mineralocorticoid receptor reverses adipocyte dysfunction and insulin resistance in obese mice. Cardiovascular Research 200984 164-172. (doi:10.1093/cvr/cvp191)

88 Lee MJ \& Fried SK. The glucocorticoid receptor, not the mineralocorticoid receptor, plays the dominant role in adipogenesis and adipokine production in human adipocytes. International Journal of Obesity 201438 1228-1233. (doi:10.1038/ijo.2014.6)

89 Kuhn E, Bourgeois C, Keo V, Viengchareun S, Muscat A, Meduri G, Le Menuet D, Feve B \& Lombes M. Paradoxical resistance to high-fat diet-induced obesity and altered macrophage polarization in mineralocorticoid receptor-overexpressing mice. American Journal of Physiology. Endocrinology and Metabolism 2014306 E75-E90. (doi:10.1152/ajpendo.00323.2013)

90 Lindroos J, Husa J, Mitterer G, Haschemi A, Rauscher S, Haas R, Groger M, Loewe R, Kohrgruber N, Schrogendorfer KF et al. Human but not mouse adipogenesis is critically dependent on LMO3. Cell Metabolism 201318 62-74. (doi:10.1016/j.cmet.2013.05.020)

91 Kong X, Yu J, Bi J, Qi H, Di W, Wu L, Wang L, Zha J, Lv S, Zhang F et al. Glucocorticoids transcriptionally regulate miR-27b expression promoting body fat accumulation via suppressing the browning of white adipose tissue. Diabetes 201564 393-404. (doi:10.2337/db14-0395)
92 Jacob W, Rosenzweig D, Vazquez-Martin C, Duce SL \& Cohen PT. Decreased adipogenesis and adipose tissue in mice with inactivated protein phosphatase 5. Biochemical Journal 2015466 163-176. (doi:10.1042/BJ20140428)

93 Feng B, He Q \& Xu H. FOXO1-dependent up-regulation of MAP kinase phosphatase 3 (MKP-3) mediates glucocorticoid-induced hepatic lipid accumulation in mice. Molecular and Cellular Endocrinology 2014393 46-55. (doi:10.1016/j.mce.2014.06.001)

$94 \mathrm{Yu}$ D. Chronic glucocorticoid exposure-induced epididymal adiposity is associated with mitochondrial dysfunction in white adipose tissue of male C57BL/6J mice. PLoS ONE 20149 e112628. (doi:10.1371/ journal.pone.0112628)

95 Barclay JL, Agada H, Jang C, Ward M, Wetzig N \& Ho KK. Effects of glucocorticoids on human brown adipocytes. Journal of Endocrinology 2015224 139-147. (doi:10.1530/JOE-14-0538)

96 Rockall AG, Sohaib SA, Evans D, Kaltsas G, Isidori AM, Monson JP, Besser GM, Grossman AB \& Reznek RH. Computed tomography assessment of fat distribution in male and female patients with Cushing's syndrome. European Journal of Endocrinology 2003149 561-567. (doi:10.1530/eje.0.1490561)

97 Ueland T, Kristo C, Godang K, Aukrust P \& Bollerslev J. Interleukin-1 receptor antagonist is associated with fat distribution in endogenous Cushing's syndrome: a longitudinal study. Journal of Clinical Endocrinology and Metabolism 200388 1492-1496. (doi:10.1210/jc.2002021030)

98 Geer EB, Shen W, Gallagher D, Punyanitya M, Looker HC, Post KD \& Freda PU. MRI assessment of lean and adipose tissue distribution in female patients with Cushing's disease. Clinical Endocrinology 201073 469-475. (doi:10.1111/j.1365-2265.2010.03829.x)

99 Geer EB, Shen W, Strohmayer E, Post KD \& Freda PU. Body composition and cardiovascular risk markers after remission of Cushing's disease: a prospective study using whole-body MRI. Journal of Clinical Endocrinology and Metabolism 201297 1702-1711. (doi:10.1210/jc.2011-3123)

100 Faggiano A, Pivonello R, Spiezia S, De Martino MC, Filippella M, Di Somma C, Lombardi G \& Colao A. Cardiovascular risk factors and common carotid artery caliber and stiffness in patients with Cushing's disease during active disease and 1 year after disease remission. Journal of Clinical Endocrinology and Metabolism 200388 2527-2533. (doi:10.1210/jc.2002-021558)

101 Pivonello R, Faggiano A, Lombardi G \& Colao A. The metabolic syndrome and cardiovascular risk in Cushing's syndrome. Endocrinology and Metabolism Clinics of North America 200534 327-339, viii. (doi:10.1016/j.ecl.2005.01.010)

102 Pirlich M, Biering H, Gerl H, Ventz M, Schmidt B, Ertl S \& Lochs H. Loss of body cell mass in Cushing's syndrome: effect of treatment. Journal of Clinical Endocrinology and Metabolism 200287 1078-1084. (doi:10.1210/jcem.87.3.8321)

103 Ragnarsson O, Glad CA, Bergthorsdottir R, Almqvist EG, Ekerstad E, Widell H, Wangberg B \& Johannsson G. Body composition and bone mineral density in women with Cushing's syndrome in remission and the association with common genetic variants influencing glucocorticoid sensitivity. European Journal of Endocrinology 2015172 1-10. (doi:10.1530/EJE-14-0747)

104 Barahona MJ, Sucunza N, Resmini E, Fernandez-Real JM, Ricart W, Moreno-Navarrete JM, Puig T, Farrerons J \& Webb SM. Persistent body fat mass and inflammatory marker increases after long-term cure of Cushing's syndrome. Journal of Clinical Endocrinology and Metabolism 200994 3365-3371. (doi:10.1210/jc.2009-0766)

105 Leong GM, Abad V, Charmandari E, Reynolds JC, Hill S, Chrousos GP $\&$ Nieman LK. Effects of child- and adolescent-onset endogenous Cushing syndrome on bone mass, body composition, and growth: a 7-year prospective study into young adulthood. Journal of Bone and Mineral Research 200722 110-118. (doi:10.1359/jbmr.061010)

106 Keil MF, Graf J, Gokarn N \& Stratakis CA. Anthropometric measures and fasting insulin levels in children before and after cure of Cushing 
syndrome. Clinical Nutrition 201231 359-363. (doi:10.1016/j.clnu. 2011.11.007)

107 Resmini E, Farkas C, Murillo B, Barahona MJ, Santos A, MartinezMomblan MA, Roig O, Ybarra J, Geli C \& Webb SM. Body composition after endogenous (Cushing's syndrome) and exogenous (rheumatoid arthritis) exposure to glucocorticoids. Hormone and Metabolic Research 201042 613-618. (doi:10.1055/s-0030-1255032)

108 London E, Rothenbuhler A, Lodish M, Gourgari E, Keil M, Lyssikatos C, de la Luz Sierra M, Patronas N, Nesterova M \& Stratakis CA. Differences in adiposity in Cushing syndrome caused by PRKAR1A mutations: clues for the role of cyclic AMP signaling in obesity and diagnostic implications. Journal of Clinical Endocrinology and Metabolism 201499 E303-E310. (doi:10.1210/jc.2013-1956)

109 London E, Lodish M, Keil M, Lyssikatos C, de la Luz Sierra M, Nesterova M \& Stratakis CA. Not all glucocorticoid-induced obesity is the same: differences in adiposity among various diagnostic groups of Cushing syndrome. Hormone and Metabolic Research 201446 897-903. (doi:10.1055/s-0034-1389956)

110 Debono M, Prema A, Hughes TJ, Bull M, Ross RJ \& Newell-Price J. Visceral fat accumulation and postdexamethasone serum cortisol levels in patients with adrenal incidentaloma. Journal of Clinical Endocrinology and Metabolism 201398 2383-2391. (doi:10.1210/jc.2012-4276)

111 Libe R, Morpurgo PS, Cappiello V, Maffini A, Bondioni S, Locatelli M, Zavanone M, Beck-Peccoz P \& Spada A. Ghrelin and adiponectin in patients with Cushing's disease before and after successful transsphenoidal surgery. Clinical Endocrinology 200562 30-36. (doi:10.1111/j.1365-2265.2004.02169.x)

112 Shinahara M, Nishiyama M, Iwasaki Y, Nakayama S, Noguchi T, Kambayashi M, Okada Y, Tsuda M, Stenzel-Poore MP, Hashimoto K et al. Plasma adiponectin levels are increased despite insulin resistance in corticotropin-releasing hormone transgenic mice, an animal model of Cushing syndrome. Endocrine Journal 200956 879-886. (doi:10.1507/endocrj.K09E-038)

113 Fallo F, Scarda A, Sonino N, Paoletta A, Boscaro M, Pagano C, Federspil G $\&$ Vettor R. Effect of glucocorticoids on adiponectin: a study in healthy subjects and in Cushing's syndrome. European Journal of Endocrinology 2004150 339-344. (doi:10.1530/eje.0.1500339)

114 Ashizawa N, Takagi M, Seto S, Suzuki S \& Yano K. Serum adiponectin and leptin in a patient with Cushing's syndrome before and after adrenalectomy. Internal Medicine 200746 383-385. (doi:10.2169/ internalmedicine.46.6142)

115 Valassi E, Biller BM, Klibanski A \& Misra M. Adipokines and cardiovascular risk in Cushing's syndrome. Neuroendocrinology 2012 95 187-206. (doi:10.1159/000330416)

116 Krsek M, Silha JV, Jezkova J, Hana V, Marek J, Weiss V, Stepan JJ \& Murphy LJ. Adipokine levels in Cushing's syndrome; elevated resistin levels in female patients with Cushing's syndrome. Clinical Endocrinology 200460 350-357. (doi:10.1111/j.1365-2265.2003.01987.x)

117 Lemke U, Krones-Herzig A, Berriel Diaz M, Narvekar P, Ziegler A, Vegiopoulos A, Cato AC, Bohl S, Klingmuller U, Screaton RA et al. The glucocorticoid receptor controls hepatic dyslipidemia through Hes1. Cell Metabolism 20088 212-223. (doi:10.1016/j.cmet.2008.08.001)

118 Lavery GG, Zielinska AE, Gathercole LL, Hughes B, Semjonous N, Guest P, Saqib K, Sherlock M, Reynolds G, Morgan SA et al. Lack of significant metabolic abnormalities in mice with liver-specific disruption of $11 \beta$-hydroxysteroid dehydrogenase type 1. Endocrinology 2012153 3236-3248. (doi:10.1210/en.2012-1019)

119 Li G, Hernandez-Ono A, Crooke RM, Graham MJ \& Ginsberg HN. Effects of antisense-mediated inhibition of 11ß-hydroxysteroid dehydrogenase type 1 on hepatic lipid metabolism. Journal of Lipid Research 201152 971-981. (doi:10.1194/jlr.M013748)

120 Rockall AG, Sohaib SA, Evans D, Kaltsas G, Isidori AM, Monson JP, Besser GM, Grossman AB \& Reznek RH. Hepatic steatosis in Cushing's syndrome: a radiological assessment using computed tomography. European Journal of Endocrinology 2003149 543-548. (doi:10.1530/eje. $0.1490543)$
121 Tauchmanova L, Rossi R, Biondi B, Pulcrano M, Nuzzo V, Palmieri EA, Fazio S \& Lombardi G. Patients with subclinical Cushing's syndrome due to adrenal adenoma have increased cardiovascular risk. Journal of Clinical Endocrinology and Metabolism 200287 4872-4878. (doi:10.1210/jc.2001-011766)

122 Giordano R, Marinazzo E, Berardelli R, Picu A, Maccario M, Ghigo E \& Arvat E. Long-term morphological, hormonal, and clinical follow-up in a single unit on 118 patients with adrenal incidentalomas. European Journal of Endocrinology 2010162 779-785. (doi:10.1530/EJE-09-0957)

123 Masserini B, Morelli V, Palmieri S, Eller-Vainicher C, Zhukouskaya V, Cairoli E, Orsi E, Beck-Peccoz P, Spada A \& Chiodini I. Lipid abnormalities in patients with adrenal incidentalomas: role of subclinical hypercortisolism and impaired glucose metabolism. Journal of Endocrinological Investigation 201538 623-628. (doi:10.1007/ s40618-014-0232-0)

124 Fardet L, Cabane J, Kettaneh A, Lebbe C \& Flahault A. Corticosteroidinduced lipodystrophy is associated with features of the metabolic syndrome. Rheumatology 200746 1102-1106. (doi:10.1093/rheumatology/kem062)

125 Choi HK \& Seeger JD. Glucocorticoid use and serum lipid levels in US adults: the Third National Health and Nutrition Examination Survey. Arthritis and Rheumatism 200553 528-535. (doi:10.1002/art.21329)

126 Xu C, He J, Jiang H, Zu L, Zhai W, Pu S \& Xu G. Direct effect of glucocorticoids on lipolysis in adipocytes. Molecular Endocrinology 200923 1161-1170. (doi:10.1210/me.2008-0464)

127 Shen WJ, Patel S, Miyoshi H, Greenberg AS \& Kraemer FB. Functional interaction of hormone-sensitive lipase and perilipin in lipolysis. Journal of Lipid Research 200950 2306-2313. (doi:10.1194/jlr. M900176-JLR200)

128 Appel B \& Fried SK. Effects of insulin and dexamethasone on lipoprotein lipase in human adipose tissue. American Journal of Physiology 1992262 E695-E699.

129 Fried SK, Russell CD, Grauso NL \& Brolin RE. Lipoprotein lipase regulation by insulin and glucocorticoid in subcutaneous and omental adipose tissues of obese women and men. Journal of Clinical Investigation 199392 2191-2198. (doi:10.1172/JCI116821)

130 Ottosson M, Vikman-Adolfsson K, Enerback S, Olivecrona G \& Bjorntorp P. The effects of cortisol on the regulation of lipoprotein lipase activity in human adipose tissue. Journal of Clinical Endocrinology and Metabolism 199479 820-825. (doi:10.1210/jcem.79.3.8077367)

131 Campbell JE, Peckett AJ, D’Souza AM, Hawke TJ \& Riddell MC. Adipogenic and lipolytic effects of chronic glucocorticoid exposure. American Journal of Physiology. Cell Physiology 2011300 C198-C209. (doi:10.1152/ajpcell.00045.2010)

132 Bagdade JD, Yee E, Albers J \& Pykalisto OJ. Glucocorticoids and triglyceride transport: effects on triglyceride secretion rates, lipoprotein lipase, and plasma lipoproteins in the rat. Metabolism: Clinical and Experimental 197625 533-542. (doi:10.1016/0026-0495(76)90007-X)

133 Manenschijn L, van den Akker EL, Lamberts SW \& van Rossum EF. Clinical features associated with glucocorticoid receptor polymorphisms. An overview. Annals of the New York Academy of Sciences 2009 1179 179-198. (doi:10.1111/j.1749-6632.2009.05013.x)

134 Morton NM. Obesity and corticosteroids: 11ß-hydroxysteroid type 1 as a cause and therapeutic target in metabolic disease. Molecular and Cellular Endocrinology 2010316 154-164. (doi:10.1016/j.mce. 2009.09.024)

135 Rosenstock J, Banarer S, Fonseca VA, Inzucchi SE, Sun W, Yao W, Hollis G, Flores R, Levy R, Williams WV et al. The 11- $\beta$-hydroxysteroid dehydrogenase type 1 inhibitor INCB13739 improves hyperglycemia in patients with type 2 diabetes inadequately controlled by metformin monotherapy. Diabetes Care 201033 1516-1522. (doi:10.2337/ dc09-2315)

136 Gylling H, Vanhanen H \& Miettinen TA. Effects of ketoconazole on cholesterol precursors and low density lipoprotein kinetics in hypercholesterolemia. Journal of Lipid Research 199334 59-67. 
137 Maher VM, Trainer PJ, Scoppola A, Anderson JV, Thompson GR \& Besser GM. Possible mechanism and treatment of o,p'DDD-induced hypercholesterolaemia. Quarterly Journal of Medicine 199284 671-679.

138 Neuvonen PJ, Niemi M \& Backman JT. Drug interactions with lipidlowering drugs: mechanisms and clinical relevance. Clinical Pharmacology and Therapeutics 200680 565-581. (doi:10.1016/j.clpt. 2006.09.003)

139 Vakili H \& Cattini PA. The hidden but positive role for glucocorticoids in the regulation of growth hormone-producing cells. Molecular and Cellular Endocrinology 2012363 1-9. (doi:10.1016/j.mce.2012.08.001)

140 Jain V, Metherell LA, David A, Sharma R, Sharma PK, Clark AJ \& Chan LF. Neonatal presentation of familial glucocorticoid deficiency resulting from a novel splice mutation in the melanocortin 2 receptor accessory protein. European Journal of Endocrinology 2011165 987-991. (doi:10.1530/EJE-11-0581)

141 McEachern R, Drouin J, Metherell L, Huot C, Van Vliet G \& Deal C. Severe cortisol deficiency associated with reversible growth hormone deficiency in two infants: what is the link? Journal of Clinical Endocrinology and Metabolism 201196 2670-2674. (doi:10.1210/jc. 2011-0129)

142 Pekic S, Doknic M, Djurovic M, Damjanovic S, Petakov M, Miljic D, Dieguez C, Casanueva FF \& Popovic V. The influence of serum cortisol levels on growth hormone responsiveness to GH-releasing hormone plus GH-releasing peptide-6 in patients with hypocortisolism. Hormones 20032 243-249. (doi:10.14310/horm.2002.11106)

143 Casanueva FF, Burguera B, Muruais C \& Dieguez C. Acute administration of corticoids: a new and peculiar stimulus of growth hormone secretion in man. Journal of Clinical Endocrinology and Metabolism 1990 70 234-237. (doi:10.1210/jcem-70-1-234)

144 Krogh J, Nordentoft M, Mohammad-Nezhad M \& Westrin A. Growth hormone, prolactin and cortisol response to exercise in patients with depression. Journal of Affective Disorders 2010125 189-197. (doi:10.1016/j.jad.2010.01.009)

145 Storr HL, Chan LF, Grossman AB \& Savage MO. Paediatric Cushing's syndrome: epidemiology, investigation and therapeutic advances. Trends in Endocrinology and Metabolism 200718 167-174. (doi:10.1016/j.tem.2007.03.005)

146 Carroll PV, Monson JP, Grossman AB, Besser GM, Plowman PN, Afshar F \& Savage MO. Successful treatment of childhood-onset Cushing's disease is associated with persistent reduction in growth hormone secretion. Clinical Endocrinology 200460 169-174. (doi:10.1046/j.1365-2265.2003.01922.x)

147 Tzanela M, Karavitaki N, Stylianidou C, Tsagarakis S \& Thalassinos NC. Assessment of GH reserve before and after successful treatment of adult patients with Cushing's syndrome. Clinical Endocrinology 200460 309-314. (doi:10.1046/j.1365-2265.2004. 01976.x)

148 Feldt-Rasmussen U, Abs R, Bengtsson BA, Bennmarker H, Bramnert M, Hernberg-Stahl E, Monson JP, Westberg B, Wilton P, Wuster C et al. Growth hormone deficiency and replacement in hypopituitary patients previously treated for acromegaly or Cushing's disease. European Journal of Endocrinology 2002146 67-74. (doi:10.1530/eje.0. 1460067)

149 van Aken MO, Pereira AM, Frolich M, Romijn JA, Pijl H, Veldhuis JD \& Roelfsema F. Growth hormone secretion in primary adrenal Cushing's syndrome is disorderly and inversely correlated with body mass index. American Journal of Physiology. Endocrinology and Metabolism 2005288 E63-E70. (doi:10.1152/ajpendo.00317.2004)

150 Pecori Giraldi F, Andrioli M, De Marinis L, Bianchi A, Giampietro A, De Martin M, Sacco E, Scacchi M, Pontecorvi A \& Cavagnini F. Significant GH deficiency after long-term cure by surgery in adult patients with Cushing's disease. European Journal of Endocrinology 2007 156 233-239. (doi:10.1530/eje.1.02329)

151 Palmieri S, Morelli V, Salcuni AS, Eller-Vainicher C, Cairoli E, Zhukouskaya VV, Beck-Peccoz P, Scillitani A \& Chiodini I.
GH secretion reserve in subclinical hypercortisolism. Pituitary 201417 470-476. (doi:10.1007/s11102-013-0528-7)

152 Mazziotti G \& Giustina A. Glucocorticoids and the regulation of growth hormone secretion. Nature Reviews. Endocrinology 20139 265-276. (doi:10.1038/nrendo.2013.5)

153 Lui JC, Nilsson O \& Baron J. Growth plate senescence and catch-up growth. Endocrine Development 201121 23-29. (doi:10.1159/ 000328117)

154 Arnaldi G, Mancini T, Tirabassi G, Trementino L \& Boscaro M. Advances in the epidemiology, pathogenesis, and management of Cushing's syndrome complications. Journal of Endocrinological Investigation 201235 434-448. (doi:10.1007/BF03345431)

155 Davies JH, Storr HL, Davies K, Monson JP, Besser GM, Afshar F, Plowman PN, Grossman AB \& Savage MO. Final adult height and body mass index after cure of paediatric Cushing's disease. Clinical Endocrinology 200562 466-472. (doi:10.1111/j.1365-2265.2005. 02244.x)

156 Lebrethon MC, Grossman AB, Afshar F, Plowman PN, Besser GM \& Savage MO. Linear growth and final height after treatment for Cushing's disease in childhood. Journal of Clinical Endocrinology and Metabolism 200085 3262-3265. (doi:10.1210/jcem.85.9.6817)

157 Webb SM, Mo D, Lamberts SW, Melmed S, Cavagnini F, Pecori Giraldi F, Strasburger CJ, Zimmermann AG \& Woodmansee WW. Metabolic, cardiovascular, and cerebrovascular outcomes in growth hormone-deficient subjects with previous cushing's disease or nonfunctioning pituitary adenoma. Journal of Clinical Endocrinology and Metabolism 201095 630-638. (doi:10.1210/jc.2009-0806)

158 Johannsson G, Sunnerhagen KS \& Svensson J. Baseline characteristics and the effects of two years of growth hormone replacement therapy in adults with growth hormone deficiency previously treated for Cushing's disease. Clinical Endocrinology 200460 550-559. (doi:10. 1111/j.1365-2265.2004.02018.x)

159 Magiakou MA, Smyrnaki P \& Chrousos GP. Hypertension in Cushing's syndrome. Best Practice \& Research. Clinical Endocrinology \& Metabolism 200620 467-482. (doi:10.1016/j.beem.2006.07.006)

160 Cicala MV \& Mantero F. Hypertension in Cushing's syndrome: from pathogenesis to treatment. Neuroendocrinology 201092 (Suppl 1) 44-49. (doi:10.1159/000314315)

161 Sato A, Suzuki H, Murakami M, Nakazato Y, Iwaita Y \& Saruta T. Glucocorticoid increases angiotensin II type 1 receptor and its gene expression. Hypertension 199423 25-30. (doi:10.1161/01.HYP.23.1.25)

162 Kelly JJ, Martin A \& Whitworth JA. Role of erythropoietin in cortisolinduced hypertension. Journal of Human Hypertension 200014 195-198. (doi:10.1038/sj.jhh.1000959)

163 Kirilov G, Tomova A, Dakovska L, Kumanov P, Shinkov A \& Alexandrov AS. Elevated plasma endothelin as an additional cardiovascular risk factor in patients with Cushing's syndrome. European Journal of Endocrinology 2003149 549-553. (doi:10.1530/eje. $0.1490549)$

164 Smith L \& Smith JB. Regulation of sodium-calcium exchanger by glucocorticoids and growth factors in vascular smooth muscle. Journal of Biological Chemistry 1994269 27527-27531.

165 Sala C, Ambrosi B \& Morganti A. Blunted vascular and renal effects of exogenous atrial natriuretic peptide in patients with cushing's disease. Journal of Clinical Endocrinology and Metabolism 200186 1957-1961. (doi:10.1210/jcem.86.5.7477)

166 Wallerath T, Witte K, Schafer SC, Schwarz PM, Prellwitz W, Wohlfart P, Kleinert H, Lehr HA, Lemmer B \& Forstermann U. Downregulation of the expression of endothelial NO synthase is likely to contribute to glucocorticoid-mediated hypertension. PNAS 199996 13357-13362. (doi:10.1073/pnas.96.23.13357)

167 Mitchell BM, Dorrance AM, Mack EA \& Webb RC. Glucocorticoids decrease GTP cyclohydrolase and tetrahydrobiopterin-dependent vasorelaxation through glucocorticoid receptors. Journal of Cardiovascular Pharmacology 200443 8-13. (doi:10.1097/00005344200401000-00002) 
168 Rizzoni D, Porteri E, De Ciuceis C, Rodella LF, Paiardi S, Rizzardi N, Platto C, Boari GE, Pilu A, Tiberio GA et al. Hypertrophic remodeling of subcutaneous small resistance arteries in patients with Cushing's syndrome. Journal of Clinical Endocrinology and Metabolism 200994 5010-5018. (doi:10.1210/jc.2009-1588)

169 Duprez DA. Role of the renin-angiotensin-aldosterone system in vascular remodeling and inflammation: a clinical review. Journal of Hypertension 200624 983-991. (doi:10.1097/01.hjh.0000226182. 60321.69)

170 Karamouzis I, Berardelli R, D’Angelo V, Fussotto B, Zichi C, Giordano R, Settanni F, Maccario M, Ghigo E \& Arvat E. Enhanced oxidative stress and platelet activation in patients with Cushing's syndrome. Clinical Endocrinology 201582 517-524. (doi:10.1111/ cen.12524)

171 Baykan M, Erem C, Gedikli O, Hacihasanoglu A, Erdogan T, Kocak M, Durmus I, Korkmaz L \& Celik S. Impairment of flow-mediated vasodilatation of brachial artery in patients with Cushing's Syndrome. Endocrine 200731 300-304. (doi:10.1007/s12020-007-0033-8)

172 Akaza I, Yoshimoto T, Tsuchiya K \& Hirata Y. Endothelial dysfunction aassociated with hypercortisolism is reversible in Cushing's syndrome. Endocrine Journal 201057 245-252. (doi:10.1507/endocrj. K09E-260)

173 Albiger N, Testa RM, Almoto B, Ferrari M, Bilora F, Petrobelli F, Pagnan A, Mantero F \& Scaroni C. Patients with Cushing's syndrome have increased intimal media thickness at different vascular levels: comparison with a population matched for similar cardiovascular risk factors. Hormone and Metabolic Research 200638 405-410. (doi:10.1055/s-2006-944545)

174 Barahona MJ, Resmini E, Vilades D, Pons-Llado G, Leta R, Puig T \& Webb SM. Coronary artery disease detected by multislice computed tomography in patients after long-term cure of Cushing's syndrome. Journal of Clinical Endocrinology and Metabolism 201398 1093-1099. (doi:10.1210/jc.2012-3547)

175 Fallo F, Famoso G, Capizzi D, Sonino N, Dassie F, Maffei P, Martini C, Paoletta A, Iliceto $\mathrm{S} \&$ Tona F. Coronary microvascular function in patients with Cushing's syndrome. Endocrine 201343 206-213. (doi:10.1007/s12020-012-9764-2)

176 Debono M, Bradburn M, Bull M, Harrison B, Ross RJ \& Newell-Price J. Cortisol as a marker for increased mortality in patients with incidental adrenocortical adenomas. Journal of Clinical Endocrinology and Metabolism 201499 4462-4470. (doi:10.1210/jc.2014-3007)

177 Morelli V, Reimondo G, Giordano R, Della Casa S, Policola C, Palmieri S, Salcuni AS, Dolci A, Mendola M, Arosio M et al. Long-term follow-up in adrenal incidentalomas: an Italian multicenter study. Journal of Clinical Endocrinology and Metabolism 201499 827-834. (doi:10.1210/jc.2013-3527)

178 Shivaprasad K, Kumar M, Dutta D, Sinha B, Mondal SA, Maisnam I, Mukhopadhyay S \& Chowdhury S. Increased soluble TNF receptor-1 and glutathione peroxidase may predict carotid intima media thickness in females with Cushing's syndrome. Endocrine Practice 2015 21 286-295. (doi:10.4158/EP14399.OR)

179 Barahona MJ, Resmini E, Vilades D, Fernandez-Real JM, Ricart W, Moreno-Navarrete JM, Pons-Llado G, Leta R \& Webb SM. Soluble TNF $\alpha$-receptor 1 as a predictor of coronary calcifications in patients after long-term cure of Cushing's syndrome. Pituitary 201518 135-141. (doi:10.1007/s11102-014-0566-9)

180 Ermetici F, Malavazos AE, Corbetta S, Eller-Vainicher C, Cannavo S, Corsi MM \& Ambrosi B. Soluble adhesion molecules levels in patients with Cushing's syndrome before and after cure. Journal of Endocrinological Investigation 200831 389-392. (doi:10.1007/BF03346381)

181 Kristo C, Ueland T, Godang K, Aukrust P \& Bollerslev J. Biochemical markers for cardiovascular risk following treatment in endogenous Cushing's syndrome. Journal of Endocrinological Investigation 200831 400-405. (doi:10.1007/BF03346383)

182 Terzolo M, Allasino B, Bosio S, Brusa E, Daffara F, Ventura M, Aroasio E, Sacchetto G, Reimondo G, Angeli A et al.
Hyperhomocysteinemia in patients with Cushing's syndrome. Journal of Clinical Endocrinology and Metabolism 200489 3745-3751. (doi:10.1210/jc.2004-0079)

183 Faggiano A, Melis D, Alfieri R, De Martino M, Filippella M, Milone F, Lombardi G, Colao A \& Pivonello R. Sulfur amino acids in Cushing's disease: insight in homocysteine and taurine levels in patients with active and cured disease. Journal of Clinical Endocrinology and Metabolism 200590 6616-6622. (doi:10.1210/jc.2005-0656)

184 Toja PM, Branzi G, Ciambellotti F, Radaelli P, De Martin M, Lonati LM, Scacchi M, Parati G, Cavagnini F \& Pecori Giraldi F. Clinical relevance of cardiac structure and function abnormalities in patients with Cushing's syndrome before and after cure. Clinical Endocrinology 2012 76 332-338. (doi:10.1111/j.1365-2265.2011.04206.x)

185 Pereira AM, Delgado V, Romijn JA, Smit JW, Bax JJ \& Feelders RA. Cardiac dysfunction is reversed upon successful treatment of Cushing's syndrome. European Journal of Endocrinology 2010162 331-340. (doi:10.1530/EJE-09-0621)

186 Kamenicky P, Redheuil A, Roux C, Salenave S, Kachenoura N, Raissouni Z, Macron L, Guignat L, Jublanc C, Azarine A et al. Cardiac structure and function in Cushing's syndrome: a cardiac magnetic resonance imaging study. Journal of Clinical Endocrinology and Metabolism 201499 E2144-E2153. (doi:10.1210/jc.2014-1783)

187 Yiu KH, Marsan NA, Delgado V, Biermasz NR, Holman ER, Smit JW, Feelders RA, Bax JJ \& Pereira AM. Increased myocardial fibrosis and left ventricular dysfunction in Cushing's syndrome. European Journal of Endocrinology 2012166 27-34. (doi:10.1530/EJE-11-0601)

188 Alexandraki KI, Kaltsas GA, Vouliotis AI, Papaioannou TG, Trisk L, Zilos A, Korbonits M, Besser GM, Anastasakis A \& Grossman AB. Specific electrocardiographic features associated with Cushing's disease. Clinical Endocrinology 201174 558-564. (doi:10.1111/j.13652265.2011.03975.x)

189 Fallo F, Maffei P, Dalla Pozza A, Carli M, Della Mea P, Lupia M, Rabbia F $\&$ Sonino N. Cardiovascular autonomic function in Cushing's syndrome. Journal of Endocrinological Investigation 200932 41-45. (doi:10.1007/BF03345677)

190 Chandran DS, Ali N, Jaryal AK, Jyotsna VP \& Deepak KK. Decreased autonomic modulation of heart rate and altered cardiac sympathovagal balance in patients with Cushing's syndrome: role of endogenous hypercortisolism. Neuroendocrinology 201397 309-317. (doi:10.1159/000345905)

191 Iacobellis G, Petramala L, Barbaro G, Kargi AY, Serra V, Zinnamosca L, Colangelo L, Marinelli C, Ciardi A, De Toma G et al. Epicardial fat thickness and left ventricular mass in subjects with adrenal incidentaloma. Endocrine 201344 532-536. (doi:10.1007/s12020-0139902-5)

192 Bassareo PP, Fanos V, Zaffanello M \& Mercuro G. Early markers of cardiovascular dysfunction in young girls affected by Cushing's syndrome before and after successful cure. Journal of Pediatric Endocrinology \& Metabolism 201023 627-635. (doi:10.1515/jpem. 2010.103)

193 Lambert JK, Goldberg L, Fayngold S, Kostadinov J, Post KD \& Geer EB. Predictors of mortality and long-term outcomes in treated Cushing's disease: a study of 346 patients. Journal of Clinical Endocrinology and Metabolism 201398 1022-1030. (doi:10.1210/jc.2012-2893)

194 Chow JT, Thompson GB, Grant CS, Farley DR, Richards ML \& Young WF Jr. Bilateral laparoscopic adrenalectomy for corticotrophindependent Cushing's syndrome: a review of the Mayo Clinic experience. Clinical Endocrinology 200868 513-519. (doi:10.1111/j. 1365-2265.2007.03082.x)

195 Iacobone M, Citton M, Scarpa M, Viel G, Boscaro M \& Nitti D. Systematic review of surgical treatment of subclinical Cushing's syndrome. British Journal of Surgery 2015102 318-330. (doi:10.1002/ bjs.9742)

196 Dekkers OM, Horvath-Puho E, Jorgensen JO, Cannegieter SC, Ehrenstein V, Vandenbroucke JP, Pereira AM \& Sorensen HT. Multisystem morbidity and mortality in Cushing's syndrome: 
a cohort study. Journal of Clinical Endocrinology and Metabolism 201398 2277-2284. (doi:10.1210/jc.2012-3582)

197 Isidori AM, Graziadio C, Paragliola RM, Cozzolino A, Ambrogio AG, Colao A, Corsello SM, Pivonello R \& ABC Study Group. The hypertension of Cushing's syndrome: controversies in the pathophysiology and focus on cardiovascular complications. Journal of Hypertension 201533 44-60. (doi:10.1097/HJH.0000000000000415)

198 Nieman LK. Medical therapy of Cushing's disease. Pituitary 20025 77-82. (doi:10.1023/A:1022308429992)

199 Donadille B, Groussin L, Waintrop C, Abbas H, Tenenbaum F, Dugue MA, Coste J, Bertagna X \& Bertherat J. Management of Cushing's syndrome due to ectopic adrenocorticotropin secretion with 1,ortho-1, para'-dichloro-diphenyl-dichloro-ethane: findings in 23 patients from a single center. Journal of Clinical Endocrinology and Metabolism 201095 537-544. (doi:10.1210/jc.2009-1317)

200 Fleseriu M, Biller BM, Findling JW, Molitch ME, Schteingart DE, Gross C \& Investigators SS. Mifepristone, a glucocorticoid receptor antagonist, produces clinical and metabolic benefits in patients with Cushing's syndrome. Journal of Clinical Endocrinology and Metabolism 201297 2039-2049. (doi:10.1210/jc.2011-3350)

201 Castinetti F, Brue T \& Conte-Devolx B. The use of the glucocorticoid receptor antagonist mifepristone in Cushing's syndrome. Current Opinion in Endocrinology, Diabetes, and Obesity 201219 295-299. (doi:10.1097/MED.0b013e32835430bf)

202 Colao A, Petersenn S, Newell-Price J, Findling JW, Gu F, Maldonado M, Schoenherr U, Mills D, Salgado LR, Biller BM et al. A 12-month phase 3 study of pasireotide in Cushing's disease. New England Journal of Medicine 2012366 914-924. (doi:10.1056/NEJMoa1105743)

203 Feelders RA, de Bruin C, Pereira AM, Romijn JA, Netea-Maier RT, Hermus AR, Zelissen PM, van Heerebeek R, de Jong FH, van der Lely AJ et al. Pasireotide alone or with cabergoline and ketoconazole in Cushing's disease. New England Journal of Medicine 2010362 1846-1848. (doi:10.1056/NEJMc1000094)

204 Pecori Giraldi F, Ambrogio AG, Andrioli M, Sanguin F, Karamouzis I, Corsello SM, Scaroni C, Arvat E, Pontecorvi A \& Cavagnini F. Potential role for retinoic acid in patients with Cushing's disease. Journal of Clinical Endocrinology and Metabolism 201297 3577-3583. (doi:10.1210/jc.2012-2328)

205 Bertagna X, Pivonello R, Fleseriu M, Zhang Y, Robinson P, Taylor A, Watson CE, Maldonado M, Hamrahian AH, Boscaro M et al. LCI699, a potent 11ß-hydroxylase inhibitor, normalizes urinary cortisol in patients with Cushing's disease: results from a multicenter, proofof-concept study. Journal of Clinical Endocrinology and Metabolism 2014 99 1375-1383. (doi:10.1210/jc.2013-2117)

206 Wajchenberg BL, Bosco A, Marone MM, Levin S, Rocha M, Lerario AC, Nery M, Goldman J \& Liberman B. Estimation of body fat and lean tissue distribution by dual energy $\mathrm{X}$-ray absorptiometry and abdominal body fat evaluation by computed tomography in Cushing's disease. Journal of Clinical Endocrinology and Metabolism 199580 2791-2794. (doi:10.1210/jcem.80.9.7673425)

207 Mills GH, Kyroussis D, Jenkins P, Hamnegard CH, Polkey MI, Wass J, Besser GM, Moxham J \& Green M. Respiratory muscle strength in Cushing's syndrome. American Journal of Respiratory and Critical Care Medicine 1999160 1762-1765. (doi:10.1164/ajrccm.160.5.9810028)

208 Minetto MA, Lanfranco F, Botter A, Motta G, Mengozzi G, Giordano R, Picu A, Ghigo E \& Arvat E. Do muscle fiber conduction slowing and decreased levels of circulating muscle proteins represent sensitive markers of steroid myopathy? A pilot study in Cushing's disease European Journal of Endocrinology 2011164 985-993. (doi:10.1530/EJE10-1169)
209 Anagnos A, Ruff RL \& Kaminski HJ. Endocrine neuromyopathies. Neurologic Clinics 199715 673-696. (doi:10.1016/S07338619(05)70339-X)

210 Minetto MA, Qaisar R, Agoni V, Motta G, Longa E, Miotti D, Pellegrino MA \& Bottinelli R. Quantitative and qualitative adaptations of muscle fibers to glucocorticoids. Muscle \& Nerve, 2015. In press. (doi:10.1002/mus.24572)

211 Schakman O, Kalista S, Barbe C, Loumaye A \& Thissen JP. Glucocorticoid-induced skeletal muscle atrophy. International Journal of Biochemistry \& Cell Biology 201345 2163-2172. (doi:10.1016/j.biocel. 2013.05.036)

212 Croxtall JD, van Hal PT, Choudhury Q, Gilroy DW \& Flower RJ. Different glucocorticoids vary in their genomic and non-genomic mechanism of action in A549 cells. British Journal of Pharmacology 2002 135 511-519. (doi:10.1038/sj.bjp.0704474)

213 Alshekhlee A, Kaminski HJ \& Ruff RL. Neuromuscular manifestations of endocrine disorders. Neurologic Clinics 200220 35-58, v-vi. (doi:10.1016/S0733-8619(03)00053-7)

214 Kilgour AH, Gallagher IJ, MacLullich AM, Andrew R, Gray CD, Hyde P, Wackerhage H, Husi H, Ross JA, Starr JM et al. Increased skeletal muscle $11 \beta H S D 1 \mathrm{mRNA}$ is associated with lower muscle strength in ageing. PLoS ONE 20138 e84057. (doi:10.1371/journal.pone.0084057)

215 Pereira RM \& Freire de Carvalho J. Glucocorticoid-induced myopathy. Joint, Bone, Spine 201178 41-44. (doi:10.1016/j.jbspin.2010.02.025)

216 Liu Z, Li G, Kimball SR, Jahn LA \& Barrett EJ. Glucocorticoids modulate amino acid-induced translation initiation in human skeletal muscle. American Journal of Physiology. Endocrinology and Metabolism 2004287 E275-E281. (doi:10.1152/ajpendo.00457.2003)

217 Son YH, Lee SJ, Lee KB, Lee JH, Jeong EM, Chung SG, Park SC \& Kim IG. Dexamethasone downregulates caveolin-1 causing muscle atrophy via inhibited insulin signaling. Journal of Endocrinology 2015 225 27-37. (doi:10.1530/JOE-14-0490)

218 Hasselgren PO. Glucocorticoids and muscle catabolism. Current Opinion in Clinical Nutrition and Metabolic Care 19992 201-205. (doi:10.1097/00075197-199905000-00002)

219 Inder WJ, Jang C, Obeyesekere VR \& Alford FP. Dexamethasone administration inhibits skeletal muscle expression of the androgen receptor and IGF-1 - implications for steroid-induced myopathy. Clinical Endocrinology 201073 126-132. (doi:10.1111/j.1365-2265. 2009.03683.x)

220 McCroskery S, Thomas M, Maxwell L, Sharma M \& Kambadur R. Myostatin negatively regulates satellite cell activation and selfrenewal. Journal of Cell Biology 2003162 1135-1147. (doi:10.1083/jcb. 200207056)

221 Welle S, Bhatt K \& Pinkert CA. Myofibrillar protein synthesis in myostatin-deficient mice. American Journal of Physiology. Endocrinology and Metabolism 2006290 E409-E415. (doi:10.1152/ajpendo.00433. 2005)

222 Mitsui T, Azuma H, Nagasawa M, Iuchi T, Akaike M, Odomi M \& Matsumoto T. Chronic corticosteroid administration causes mitochondrial dysfunction in skeletal muscle. Journal of Neurology 2002 249 1004-1009. (doi:10.1007/s00415-002-0774-5)

223 Ralliere C, Tauveron I, Taillandier D, Guy L, Boiteux JP, Giraud B, Attaix D \& Thieblot P. Glucocorticoids do not regulate the expression of proteolytic genes in skeletal muscle from Cushing's syndrome patients. Journal of Clinical Endocrinology and Metabolism 199782 3161-3164. (doi:10.1210/jcem.82.9.4221)

224 Dong Y, Silva KA, Dong Y \& Zhang L. Glucocorticoids increase adipocytes in muscle by affecting IL-4 regulated FAP activity. FASEB Journal 201428 4123-4132. (doi:10.1096/fj.14-254011)

Received 1 April 2015

Revised version received 4 June 2015

Accepted 9 June 2015 